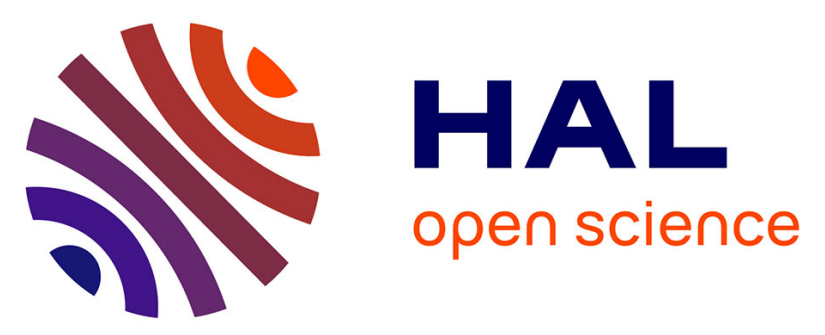

\title{
Modeling the effects of eruptive and seismic activities on flank instability at Mount Etna, Italy
}

Francesca Bozzano, Mario Gaeta, Luca Lenti, Salvatore Martino, Antonella Paciello, Danilo Mauro Palladino, Gianluca Sottili

\section{- To cite this version:}

Francesca Bozzano, Mario Gaeta, Luca Lenti, Salvatore Martino, Antonella Paciello, et al.. Modeling the effects of eruptive and seismic activities on flank instability at Mount Etna, Italy. Journal of Geophysical Research : Solid Earth, 2013, 118 (10), pp.5252-5273. 10.1002/jgrb.50377 . hal-01726615

\section{HAL Id: hal-01726615 https://hal.science/hal-01726615}

Submitted on 8 Mar 2018

HAL is a multi-disciplinary open access archive for the deposit and dissemination of scientific research documents, whether they are published or not. The documents may come from teaching and research institutions in France or abroad, or from public or private research centers.
L'archive ouverte pluridisciplinaire HAL, est destinée au dépôt et à la diffusion de documents scientifiques de niveau recherche, publiés ou non, émanant des établissements d'enseignement et de recherche français ou étrangers, des laboratoires publics ou privés. 


\title{
Modeling the effects of eruptive and seismic activities on flank instability at Mount Etna, Italy
}

\author{
F. Bozzano, ${ }^{1}$ M. Gaeta,${ }^{1}$ L. Lenti, ${ }^{2}$ S. Martino, ${ }^{1}$ A. Paciello, ${ }^{3}$ D. M. Palladino, ${ }^{1}$ \\ and G. Sottili ${ }^{4}$ \\ Received 29 January 2013; revised 16 September 2013; accepted 18 September 2013; published 24 October 2013.
}

[1] The identification and evaluation of trigger mechanisms for volcano flank instabilities and/or collapse represent a key issue for risk assessment in densely populated volcanic areas, as well as in long-distance settings, particularly in case of island or coastal volcanoes. Here we address quantitatively the effects of external (seismic) and inner (magmatic) forcing on the stress-strain state associated to flank instabilities at Mount Etna (Sicily, southern Italy) by means of a 2-D finite difference method numerical modeling. Modeled seismic actions include strong near-field, strong far-field, and low-magnitude near-field earthquakes. Magmatic actions consider the inner pressure changes induced by energetic lava fountains in the summit crater area and subvertical and oblique dike ascent below the summit area. Model results are validated in light of available monitoring data and recent eruptive activity. Numerical results show that the main strain effects are produced by high-magnitude near-field earthquakes (expected return time of $\sim 10^{3}$ yrs) and by vertical uprise of a magma dike below the volcano summit area. Maximum displacements in the order of tens of centimeters may involve the summit area, up to some $10^{6} \mathrm{~m}^{3} / \mathrm{m}$ over some kilometers laterally. Stress releases up to $10^{7} \mathrm{~Pa}$ may affect a limited portion of the magmatic conduit, thus favoring major effusive flank eruptions. Major catastrophic events, such as volcano flank collapse, should not be expected by applying, either individually or combined, the aforementioned actions.

Citation: Bozzano, F., M. Gaeta, L. Lenti, S. Martino, A. Paciello, D. M. Palladino, and G. Sottili (2013), Modeling the effects of eruptive and seismic activities on flank instability at Mount Etna, Italy, J. Geophys. Res. Solid Earth, 118, 5252-5273, doi:10.1002/jgrb.50377.

\section{Introduction}

[2] Volcano flank instability has been described in many volcanoes on Earth and other planets [e.g., Siebert, 1984; McGuire et al., 1996; Vidal and Merle, 2000; Waythomas, 2012]. Slow, continuous aseismic slip and/or "catastrophic" flank collapse events are documented by structural, morphological, geodetic, and geophysical evidence. Since the 1980 Mount St. Helens debris avalanche event [e.g., Voight et al., 1981], intensive monitoring and research activities focused on large volcanic mass movements [Lipman and Mullineaux, 1981; Duffield et al., 1982; Moore et al., 1989; Holcomb and Searle, 1991; Moore et al., 1994; Clague and

\footnotetext{
${ }^{1}$ Dipartimento di Scienze della Terra, Sapienza-Università di Roma, Rome, Italy.

${ }^{2}$ French Institute for Science and Technology for Transport, Development and Networks, Paris East University, Paris, France.

${ }^{3}$ Agenzia Nazionale per le Nuove Tecnologie, l'Energia e lo Sviluppo Economico Sostenibile, Rome, Italy.

${ }^{4}$ Istituto di Geologia Ambientale e Geoingegneria, CNR, Rome, Italy.

Corresponding author: S. Martino, Dipartimento di Scienze della Terra, Sapienza-Università di Roma, P.le A.Moro 5, Rome IT-00185, Italy. (salvatore.martino@uniroma1.it)

(C)2013. American Geophysical Union. All Rights Reserved. 2169-9313/13/10.1002/jgrb.50377
}

Denlinger, 1994; Masson, 1996; McGuire, 1996; Day et al., 1999a, 1999b; McGuire, 2006]. Mechanisms that produce volcano flank deformations include spreading and/or slumping, basal décollements, landslides, and flank failures [e.g., González et al., 2010], whereas mass movements can involve up to hundreds of cubic kilometers with runout distances up to hundreds of kilometers [Siebert, 1984; Moore et al., 1989]. Based on flank slope as the characteristic parameter, two different geometries of volcano flank instabilities can be distinguished [Day et al., 1999a, 1999b]: (i) gently sloping, Kilauean-like volcanoes, typically associated with high-flank deformation dynamics, and (ii) steep-sided, Macaronesian-like volcanoes, typically associated with low ground deformation. Possible triggers for volcano flank gravitational collapse include earthquake-induced flank failures, shallow cryptodome emplacement (e.g., Bezymianny 1956 A.D.; Mount St. Helens 1980 A.D.), reactivation of local basement faults induced by the growth of volcano edifices (e.g., 7500 B.P. Socompa, Chile), inflation of the volcanic cone due to a magma recharge event or degassing (e.g., Tata Sabaya, Bolivia), and asymmetric volcano growth [De Silva et al., 1993; Davidson and De Silva, 1999 and references therein].

[3] The hazard posed by volcano flank collapses, in addition to the direct impact of debris avalanches, is also related to the occurrence of explosive eruptions (lateral blasts) triggered by the sudden decompression of shallow magma reservoirs due 

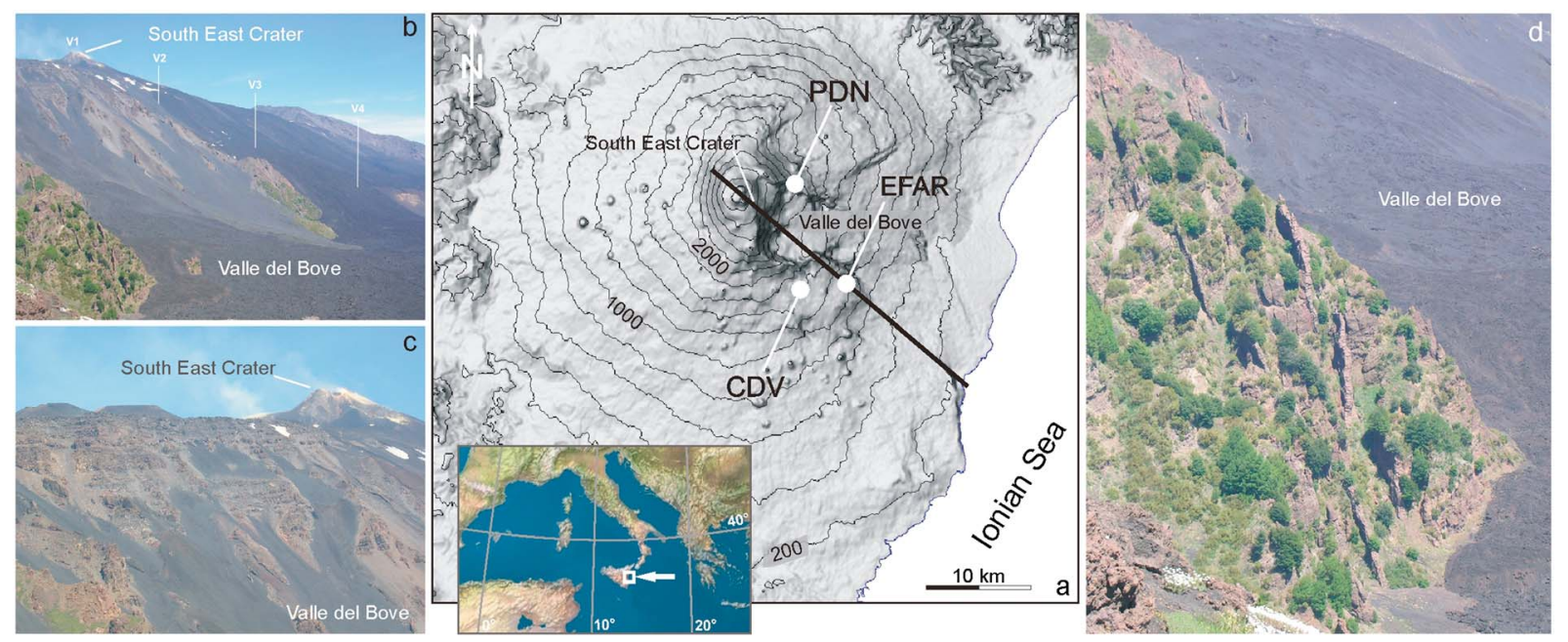

Figure 1. (a) Location of Mount Etna volcano. The trace of the geological cross section of Figure 2a and the INGV tilt monitoring stations (PDN, EFAR, CDV) [Bonaccorso et al., 2002; Bonaccorso, 2006] are also reported. (b) Panoramic view of the upper portion of the SE volcano flank. The locations of the vertical scan lines V1-V4 (see Figure 7) are also reported. (c) Detail of the SE wall of the Valle del Bove depression, which exposes the products of the Trifoglietto, Cuvigghiuni, and Ellittico volcanic edifices. (d) Detail of dike intrusions in the Trifoglietto volcanics, exposed along the Valle del Bove walls.

to the slope failure [Siebert et al., 1987]. Flank collapses at island or coastal volcanoes may also trigger tsunamis that affect coastal regions on a very large scale [Giachetti et al., 2011].

[4] The intrinsic complexity and uncertainty of these phenomena and their potential impacts have been addressed by numerical and analogue models, which simulate flank destabilization and catastrophic collapse at stratovolcanoes [e.g., Donnadieu and Merle, 1998; Lagmay et al., 2000; Vidal and Merle, 2000; Acocella, 2005; Sottili et al., 2007; Andrade and Van Wyk de Vries, 2010]. Input data for numerical simulation of volcano flank instability may derive from volcano monitoring (e.g., seismic, GPS, tilt and SAR data), geological and structural studies, and analogue models. Recent numerical modeling addressed the volcanic deformation and flank instability at Mount Etna due to tidal forcing [Sottili et al., 2007], deep magmatic sources [ 6 km below the volcano edifice; Cianetti et al., 2012] and magmatic or tectonic activities [Apuani et al., 2013].

[5] Here, we address the effects of magma dynamics and seismic activity on flank instability at Mount Etna, in light of 2-D stress-strain finite-difference-method (FDM) numerical modeling, suitable for simulating stress-strain effects at large deformations. Our stress-strain analysis is based on a detailed engineering-geological model of the volcano edifice, implemented from Sottili et al. [2007]. Different from Cianetti et al. [2012] and Apuani et al. [2013], where a homogeneous and isotropic volcanic edifice is assumed, here the different portions of the volcano and the main anisotropies related to its volcano-tectonic architecture are also taken into account, based on available geologic reconstructions [Branca et al., 2009, 2011a, 2011b, and references therein]. To this aim, for each volcano portion, the main anisotropies were modeled in terms of attitude and strength parameters of the joints. Moreover, the numerical modeling focuses on the strain effects induced by inner pressures applied within the volcano edifice ( $0-3 \mathrm{~km}$ above sea level), as well as on external dynamic actions (i.e., characterized by high-magnitude and/or low-frequency spectral content) capable to interact with specific portions of the volcano. The response of ongoing gravitational deformations of the eastern volcano flank (see section 2) to inner (i.e., preeruptive and syneruptive inner pressure variations) and external (i.e., local and far-field earthquakes) triggers is modeled by taking into account rock mass heterogeneities in the volcanic edifice, magma properties, and available measurements of volcanotectonic deformations.

[6] We illustrate three cases of inner forcing and related effects in terms of volcano flank deformation:

[7] 1. pressure variations related to nearly steady state flow of gas-pyroclast mixtures in the conduit during energetic lava fountain activity at the Southeast Crater (SEC), observed since 1998 to present;

[8] 2. the buoyant rise of a subvertical dike below the summit area, as documented to have occurred repeatedly over the last decades of activity (e.g., 1971-2003);

[9] 3. the transient migration of a shallow, overpressured, oblique magma dike preceding major lava effusion through a fissure vent along the SE volcano slope, alike the 1991-1993 eruptive scenario.

[10] The dynamic inputs of external (seismic) forcing were applied by taking into account the local attenuation law, considering the following three scenarios: (1) the maximum expected earthquake for northeastern Sicily (derived according to a spectral equivalent approach), (2) large earthquakes $(M>7)$ felt in far-field conditions (i.e., the Greek earthquakes recorded by the Italian accelerometric network, Rete Accelerometrica Nazionale (RAN)), and (3) local, long-period (LP) seismic events recorded by the RAN and by temporary broadband seismometric stations owned by the Istituto Nazionale di Geofisica e Vulcanologia (INGV). Model results show that the transient dike propagation and local LP seismicity may produce the strain fields associated to the most significant displacements of the eastern volcano flank, consistent with available monitoring data in the last few years. 
BOZZANO ET AL.: MODELING FLANK INSTABILITY AT MOUNT ETNA
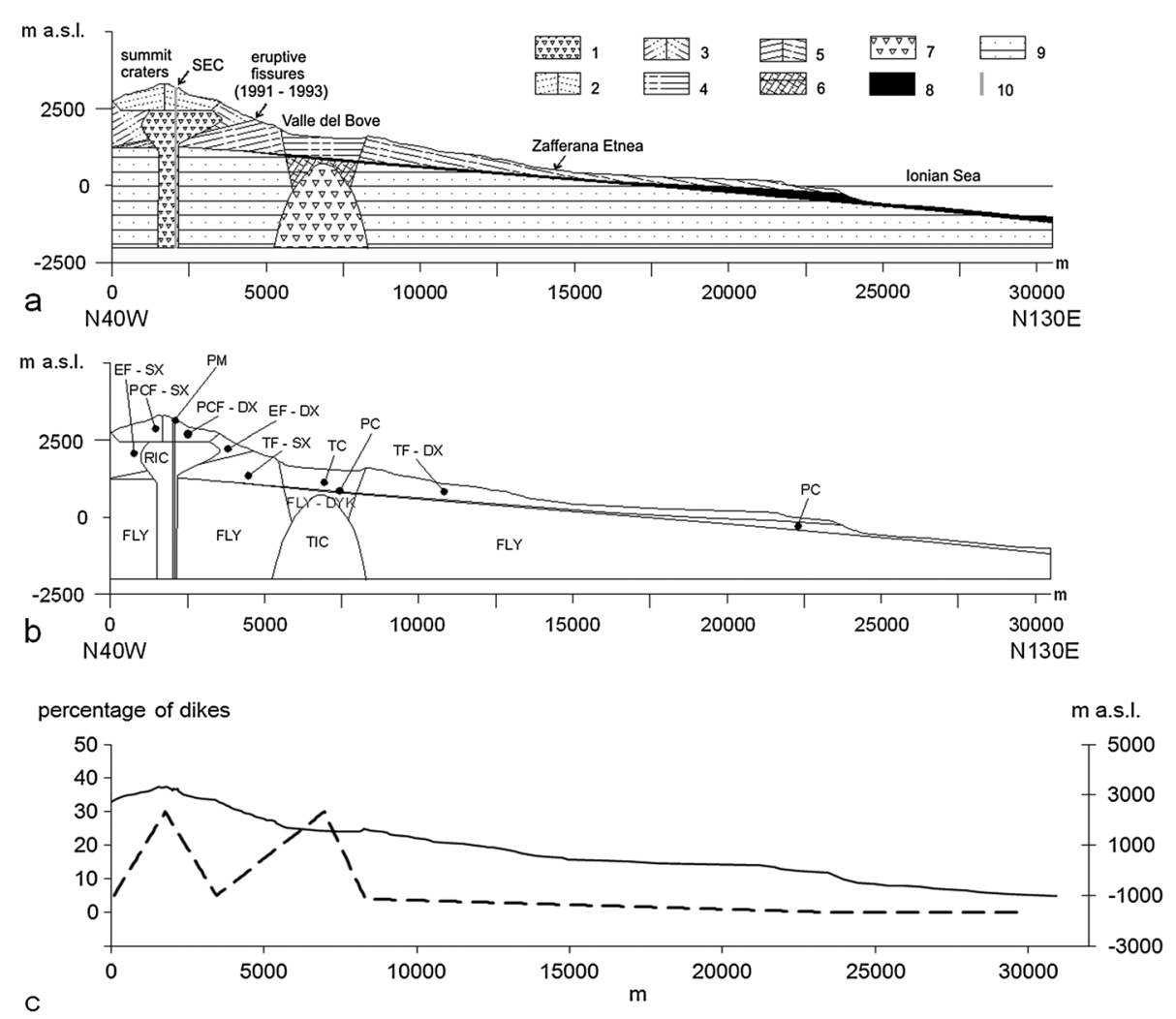

Figure 2. (a) Geological sketch section across Mount Etna along a N130 oriented trace (see Figure 1 for location); (b) engineering-geology model of the volcano edifice; (c) distribution of dike concentration in the volcanic deposits. Key to legend: (1) subvolcanic lava bodies (lava dikes, sills, plugs); (2) recent Mongibello volcanics (lava flows, scoria beds); (3) Ellittico volcanics (lava flows, scoria beds, pumiceous deposits); (4) Trifoglietto caldera-fill volcanics; (5) Trifoglietto volcanics (lava flows, pyroclastic, and secondary volcanoclastic deposits); (6) hydrothermally altered flysches, lava dikes, sills; (7) Trifoglietto intrusive body; (8) marly clays (lower-middle Pleistocene to early Quaternary); (9) marly argillaceous and arenaceous flysches (Cretaceous-Eocene); (10) SEC feeder conduit; (RIC) recent intrusive complex; (TIC) Trifoglietto intrusive complex; (DYK) dikes; (PCF-DX) Ellittico caldera-fill volcanics (right flank); (PCF-SX) Ellittico caldera fill volcanics (left flank); (TC) inferred Trifoglietto caldera; (TF-DX) Trifoglietto right flank; (TF-SX) Trifoglietto left flank; (EF-DX) Ellittico right flank; (EF-SX) Ellittico left flank; (PM) present magma; (FLY) flysch; (FLY-DYK) flysch with dike intrusions; (PC) Pliocene clays; (PC-DYK) Pliocene clays with dike intrusions.

\section{Mount Etna Flank Instability}

[11] Mount Etna, one of the most active and studied volcanoes in the world (Figure 1), is affected by flank instability dynamics, whose geometry, scale, and nature have been debated in a number of papers over the last four decades [McGuire et al., 1990; Borgia et al., 1992; Rasà et al., 1996; Rust and Neri, 1996; Calvari et al., 1998, 2004; Groppelli and Tibaldi, 1999; Borgia et al., 2000; Froger et al., 2001; Tibaldi and Groppelli, 2002; Acocella and Neri, 2003; Acocella et al., 2003; Neri et al., 2004; Sottili et al., 2007; Bonaccorso et al., 2013].

[12] In particular, different views concern the possible trigger roles of gravity and inner magma pressures. A geodetic survey along the western rim of the Valle del Bove depression (Figure 1) documented that dike emplacement during 1983 and 1985 eruptive activities caused a 2.8 m eastward displacement of a large sector of the volcano edifice, thus showing how dilation induced by magma intrusion may lead to slope instability and a progressive westward retreat of the western rim of the Valle del Bove [McGuire et al., 1990]. Lundgren et al. [2003] and Patanè et al. [2003] reported large-scale, eastward volcano flank spreading, driven by deep (5 km below sea level) magma injection, inferred to have occurred during the 1993-1995 magma inflation episode. Recently, interferometric synthetic aperture radar (InSAR) data collected from 1994 to 2008 [Ruch et al., 2010; Solaro et al., 2010] show that magma inflation phases were accompanied by eastward and westward slip on the eastern and western flanks, respectively.

[13] Borgia et al. [1992] and Merle and Borgia [1996] proposed a different view of Mount Etna flank instability, as a result of a relatively steady, gravity-driven motion in the form of deep-seated spreading over the basal décollement. In addition, the observed increase in the activity of faults along the upper portion of the volcano edifice during magma inflation episodes suggests a dominant magma-driven mechanism for the shallow deformation [e.g., Rust et al., 2005]. A synthesis between the deep-seated, gravity-driven, and the shallow, magma-driven, origin of flank deformations was proposed 


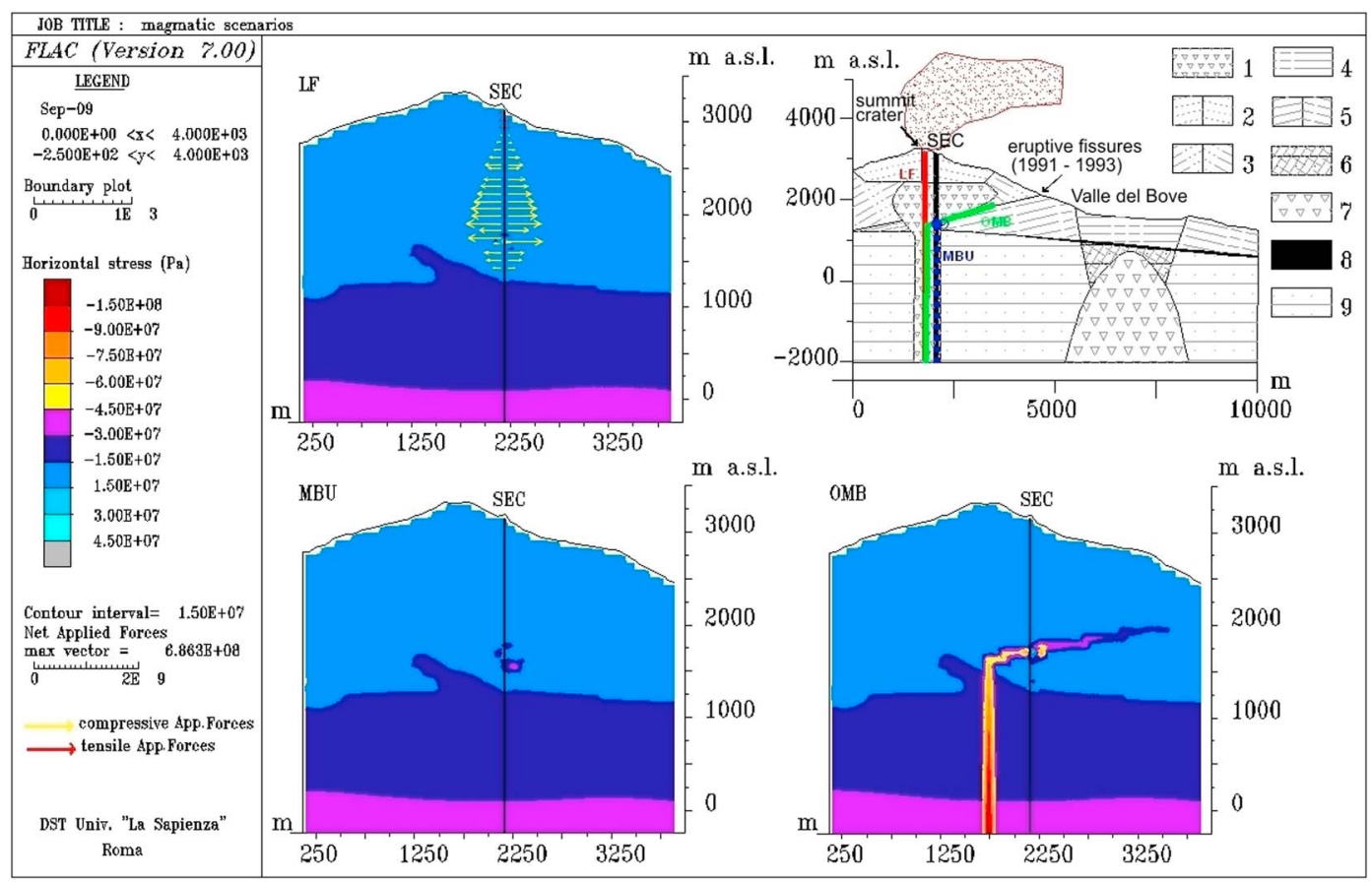

Figure 3. Magmatic scenarios (paroxysmal lava fountaining_LF, vertical magma batch uprise-MBU, oblique magma batches - OMB) modeled by the FDM numerical code (see text for details). Key to legend: (1) subvolcanic lava bodies (lava dikes, sills, plugs); (2) recent Mongibello volcanics (lava flows, scoria beds); (3) Ellittico volcanics (lava flows, scoria beds, pumiceous deposits); (4) Trifoglietto caldera fill volcanics; (5) Trifoglietto volcanics (lava flows, pyroclastic, and secondary volcanoclastic deposits); (6) hydrothermally altered flysches, lava dikes, sills; (7) Trifoglietto intrusive body; (8) marly clays (lower-middle Pleistocene; (9) marly argillaceous and arenaceous flysches (Cretaceous-Eocene).

by the "nested model" [Rust et al., 2005]. According to the latter model, the occurrence of windows of deformed sedimentary substrate at anomalously high altitudes - along with structural evidence of 1 order of magnitude slip rate variations along individual fault systems governing the volcano spreading - can be explained by multiple unstable areas, nested in plan view, with a basal décollement occurring at different elevations within the volcano edifice.

[14] The geologic history of Mount Etna possibly suggests that unusually explosive eruptions of relatively mafic magmas were triggered by sector collapse events, resulting in sudden decompression of shallow magma bodies [Coltelli et al., 1998; Giordano and Dingwell, 2003; Corsaro and Pompilio, 2004]. Finally, even relatively weak decompressions induced by Earth tide stresses may affect significantly the recent explosive activity at Mount Etna [Sottili et al., 2007] and should be considered in a comprehensive hazard assessment.

[15] On these grounds, we model the control of magmatic and seismic actions on the disequilibrium state of Mount Etna, with focus on the eastern volcano flank, which records the most intense deformation rate over the last few decades.

\section{Geological Model of Mount Etna}

\subsection{Geological Setting}

[16] We consider a geological sketch section of Mount Etna, about $30 \mathrm{~km}$ across, obtained along the azimuthal direction $130^{\circ}$ from the summit crater area to the Ionian Sea (Figures 1a and 2a), crossing the SEC and the Valle del Bove depression. In particular, our numerical model (sections 4 and 5) focuses on the stress-strain effects resulting along the most unstable slope sector between these two prominent volcano-tectonic features.

[17] The study cross section takes into account the key elements of the complex geological-structural setting of the volcano obtained from field and geophysical data [Lentini, 1982; McGuire, 1982; Guest et al., 1984; Ferrari et al., 1991; Neri et al., 1991; Borgia et al., 1992; Calvari et al., 1994; Coltelli et al., 1994; Azzaro et al., 2000, 2012; Aloisi et al., 2002; Tibaldi and Groppelli, 2002; Catalano et al., 2004; Branca et al., 2009, 2011a, 2011b; Branca and Ferrara, 2013].

[18] The prevolcanic substrate consists of CretaceousEocene marly and arenaceous flysch, overlain by lower-middle Pleistocene marly clays. The present-day stratovolcano is the result of the superposition of multiple edifices (i.e., the main Trifoglietto, Ellittico, and Mongibello volcanoes and several minor ones; see Branca et al. [2009, 2011a, 2011b], De Beni et al. [2011], and references therein, for a comprehensive reconstruction of Mount Etna evolution) that record a northwestward migration of eruptive sources through time from the Ionian coast to the presently active vent area. Each volcanic edifice is characterized by different assemblages of the rock masses, both in terms of lithologies (i.e., relative contents of pyroclastic and lava layers, intrusive bodies, and dikes) and geometric anisotropies (attitude of the volcanic deposits and paleotopography). Based on geophysical data [Rollin et al., 2000; Patanè et al., 2003, 2006], the presence of an intrusive body is inferred below the Valle del Bove depression, possibly related to the old magma reservoir of the Trifoglietto Volcano. All around the intrusive body, pervasive dikes are injected in 
Table 1. Input Parameters for Numerical Modeling of Energetic Lava Fountaining at the SEC Through CONFLOW Code ${ }^{\mathrm{a}}$

\begin{tabular}{lcc}
\hline Parameter & Values/Type & References \\
\hline Water content & $3.4 \mathrm{wt} \%$ & 1 \\
Magma composition & see Table A1 & 1 \\
Temperature & $1100^{\circ} \mathrm{C}$ & 2 \\
Crystals & $10-30 \mathrm{wt} \%$ & 3 \\
Main crystal phases & plagioclase & 1 \\
Conduit diameter (top) & $15 \mathrm{~m} ; 10-16 \mathrm{~m}$ & $3 ; 4$ \\
Conduit diameter (bottom) & $15 \mathrm{~m}$ & 5 \\
Conduit length & $1500 \mathrm{~m} ; 1500-1900 \mathrm{~m}$ & $2 ; 4$ \\
Lithostatic pressure at $1700 \mathrm{~m}$ depth & $60 \mathrm{MPa}$ & $2 ; 5$ \\
Maximum exit velocity & $150 \pm 15 \mathrm{~m} / \mathrm{s}$ & 6 \\
(event 24 June 2000) & & \\
Jet zone maximum $H$ & up to $900 \mathrm{~m}$ & 2 \\
Mass eruption rate peak & $10^{6} \mathrm{~kg} / \mathrm{s}$ & 7 \\
Exit velocity of the magma & $100-250 \mathrm{~m} / \mathrm{s}$ & 8 \\
\hline
\end{tabular}

${ }^{\mathrm{a}}$ The initial velocity of magma in the conduit is assumed at $1 \mathrm{~m} / \mathrm{s}$, the pressure at the conduit exit is calculated at SEC altitude, conduit shape is assumed as cylindrical. References are (1) Métrich et al. [2004], (2) Allard et al. [2005], (3) Dobran and Coniglio [1996], (4) Bonaccorso [2006], (5) Sottili et al. [2007], (6) Behncke et al. [2006], (7) Calvari et al. [1991], and (8) present work.

${ }^{\mathrm{b}}$ Values obtained by iterative runs from CONFLOW Code modeling.

the Meso-Cenozoic sedimentary substrate, as well as in the Trifoglietto volcanics. Although clear structural and geomorphic evidence is lacking, the presence of a collapse caldera cutting the Trifoglietto Volcano can be inferred [e.g., Branca et al., 2011b] (Figure 2a). A younger subvolcanic body is located below the present summit crater area and is crossed by the SEC feeder conduit.

\subsection{Volcanic Activity: Magmatic Scenarios}

[19] In this section, we consider three scenarios of interest (Figure 3), which refer to three different eruption dynamics and related magma feeder geometries typical of recent activity at Mount Etna, according to field observations and literature data. For each eruptive scenario, we first illustrate the theoretical background for inner pressure calculations, then we describe model application to derive the induced stress-strain effects, in light of specific thermodynamic properties of the magma, conduit and dikes geometries, and eruptive styles:

[20] 1. Paroxysmal lava fountaining (LF) at the Southeast Crater. Violent Strombolian activity, characterized by energetic lava fountaining and associated convective plumes up to $6 \mathrm{~km}$ high above sea level (asl) [Scollo et al., 2009], occurred several times at the SEC since 1998 to present. At Mount Etna, this style of activity may occasionally reach sub-Plinian intensity, as reported in recent times at SEC (5 January 1990 event) [Calvari et al., 1991] and at one of the central craters (22 July 1998 event) [Andronico et al., 2008]. Magma ascent dynamics during paroxysmal activity at Mount Etna was already investigated through numerical simulations [Dobran and Coniglio, 1996]. Our analysis bears on along-conduit pressures, as input parameters for stressstrain numerical modeling, which were calculated through the CONFLOW Code, a numerical program for steady state flow of magma-gas mixtures through vertical eruptive conduits [Mastin and Ghiorso, 2000]. For CONFLOW calculations, we refer to literature data on magma composition and physical properties (see Table 1 and Appendix A). We iteratively varied the initial magmatic overpressure, $p_{e}$, at the SEC conduit base, and conduit diameter, to obtain eruptive parameters (i.e., peak and average mass eruption rates, maximum ejection velocity, jet zone height) during violent Strombolian activity in the range of values calculated and/or measured at SEC by previous works.

[21] 2. Magma batch uprise (MBU) below the summit area. The role of transient subvertical migration of an overpressured magma dike as source of deformation at Mount Etna. Based on the 2001 eruption scenario [Acocella and Neri, 2003], a summit eruption in the SEC area was followed by (and partly concomitant to) a major peripheral effusive phase through an independent feeder system. Here we focus on the eruption onset, which was fed by residual magma from the summit feeder system. Specifically, we model the initial subvertical dike propagation below the SEC area, which is more relevant in terms of deformation expected along the unstable western wall of the Valle del Bove (Figure 1) than the peripheral dike propagation. Model details for the calculation of the static magmatic overpressure, $\Delta P$, induced by the upward migration of a dike, are reported in Appendix A. Numerical modeling yields $\Delta P=51.5 \mathrm{MPa}$.

[22] 3. Transient, oblique migration of overpressured magma batches (OMB). This model scenario was chosen in light of the 1991-1993 eruption, one of the most prolonged and volumetrically significant occurred at Mount Etna over the last three centuries [Bonaccorso et al., 1994]. This eruption was associated with marked ground deformation, measured by different geodetic techniques (EDM, GPS, leveling, and tiltmetry) [Bonaccorso, 1996]. The inferred geometry of the eruption feeder system [Murray, 1994; Rymer et al., 1994], includes the injection of a deeper, vertical, dike portion beneath the central crater area and a shallower, oblique, dike portion extending from $\sim 1600 \mathrm{~m}$ asl to the eruptive fissures, located at $\sim 2300 \mathrm{~m}$ asl along the western wall of the Valle del Bove (Figure 1). The static magmatic overpressure, $\Delta P$, induced by dike migration, was calculated following Gudmundsson [1999].

\subsection{Seismicity}

[23] Dynamic actions related to external natural events could also affect the Mount Etna volcano system and influence both its activity and ongoing gravitational deformations along the southeastern slope. A previous paper [Sottili et al., 2007] highlighted the effects of tidal accelerations. Here we deal with the actions of earthquakes, whose wave parameters significantly differ from tidal ones.

[24] The record of seismicity affecting Mount Etna volcano area was analyzed in order to derive the most likely seismic scenarios, according to local macroseismic felt data, local and Mediterranean seismogenetic sources, magnitude and location of the main earthquakes, and frequency content of the available instrumental data. In particular, these scenarios should be representative of both the maximum expected dynamic actions and the actions characterized by a relevant low-frequency content (i.e., consistent with the dimension of the Etna Volcano system) though of lower intensity.

\subsubsection{Felt Seismicity}

[25] The Calabrian arc and eastern Sicily represent a seismically very active zone (Figure 4) within the Mediterranean area that includes the epicenters of strong historical earthquakes [Azzaro and Barbano, 2000; Monaco and Tortorici, 2000; CPTI04, 2004; DISS03, 2003; CPTI11, 2011; DBMI11, 2011], 


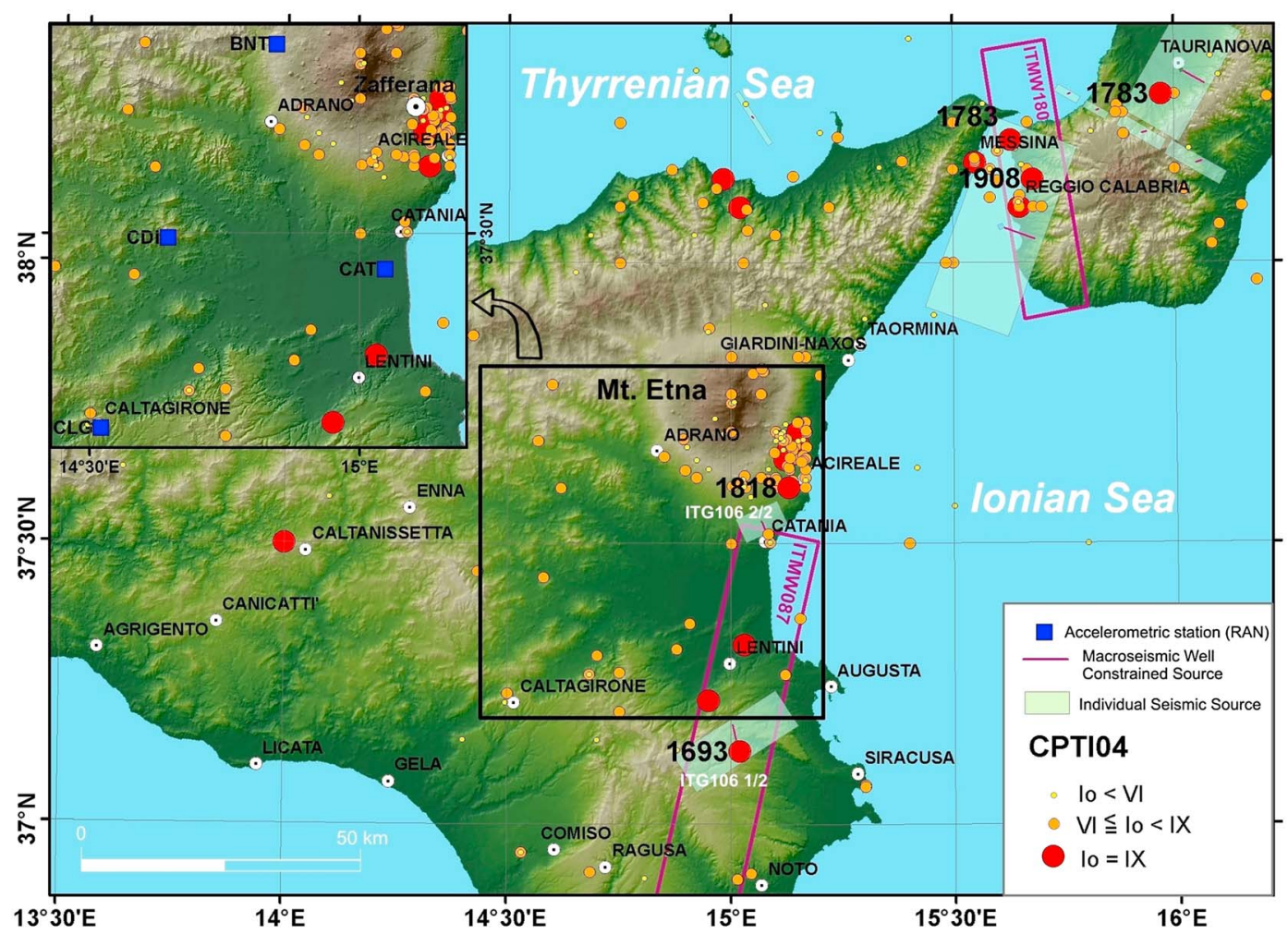

Figure 4. Map of historical seismicity and seismogenetic sources in the eastern Sicily. The historical seismicity, based on the CPTI04 [2004] catalogue, is plotted by colored epicentral circles corresponding to different values of macroseismic intensity $\left(\mathrm{I}_{0}-\mathrm{MCS}\right.$ ). The seismogenetic sources (from the DISSO3 [2003] database) are bounded by rectangles with the relative identification labels. The locations of the accelerometric stations of the Italian National Accelerometric network (BNT, CAT, CDI, CLG) are also reported in the zoomed window.

such as the 1783 "Terremoto delle Calabrie" sequence, the 1908 "Reggio e Messina" earthquake, the 1693 "Sicilia Orientale" earthquake, which reached a macroseismic intensity of XI $\operatorname{MCS}(6<M<7.4)$.

[26] Several accelerometric stations of the Italian National Network (RAN), owned by the Italian National Department for Civil Protection, operate in eastern Sicily (see zoomed window in Figure 4). These stations record also the strong, far-field earthquakes generated by the eastern Mediterranean sources, particularly in the Aegean sector [Kouskouna and Makropoulos, 2004]. Table 2 lists the strongest historical earthquakes documented between 400 B.C. and 600 A.D. in the Aegean area [CFTI04 Med, 2004]: The 365 A.D. Crete earthquake is regarded as the most damaging event (estimated magnitude 8.3-8.5) [Shaw et al., 2008], which struck the whole Eastern Mediterranean region and induced a very strong tsunami.

[27] An analysis of the Italian Macroseismic Database [DBMI1 1, 2011] for the Etnean area (Table 3), points out that

[28] 1. the maximum felt intensity (VIII MCS) at Zafferana Etnea, the closest village to the SE volcano slope is reported for the 20 February 1818 "Catanese" earthquake and the 28 December 1908 "Reggio e Messina" earthquake;

[29] 2. the local catalogue of Zafferana Etnea is incomplete, since it lacks data earlier than the year 1818, while in the previous centuries, the city of Catania (about $20 \mathrm{~km}$ away) results to have felt two strong earthquakes (A.D. 1169 and 1693), with local intensities up to X MCS;
[30] 3. the macroseismic fields of the main historical earthquakes make it possible to estimate the local intensities at Zafferana Etnea in lack of direct data: On these grounds, the 1169 and 1693 eastern Sicily earthquakes appear to be the most damaging events, with local intensities up to X MCS;

[31] 4. the maximum felt intensity (X MCS) in the whole Etnean area is related to the 11 January 1693 "Sicilia Orientale" earthquake $\left(M_{e} 7.4\right)$, which represents the strongest earthquake reported in the Italian catalogues. Although this event has not yet been associated univocally to an individual seismogenetic source, given the wide elongation of

Table 2. Strong Historical Earthquakes in the Eastern Mediterranean Area Between 400 B.C. and 600 A.D. (CFTI04 Med [2004] Catalogue)

\begin{tabular}{lcc}
\hline Year (Range) & Location & $\begin{array}{c}\text { Maximum Intensity } \\
\text { (range-MCS) }\end{array}$ \\
\hline 412-411 B.C. & Kos Island & IX-XI \\
227 B.C. & Rodi Island & IX-XI \\
198-199 B.C. & Rodi Island & IX-XI \\
53 A.D. & Crete Island & VIII-X \\
334-335 A.D. & Kos Island & VIII-X \\
344 A.D. & Rodi Island & IX-XI \\
361/363 A.D. & Greece & IX-XI \\
365 A.D. & Crete Island & X-XI \\
408-450 A.D. & Crete Island & VIII-X \\
474-478 A.D. & Rodi Island & VIII-X \\
515 A.D. & Rodi Island & VIII-X \\
554-558 A.D. & Kos Island & IX-X \\
\hline
\end{tabular}


Table 3. Felt Seismic Intensities at Zafferana Etnea and Catania and Main Features of the Related Earthquakes (From DBMI11 and DISS2003) ${ }^{\mathrm{a}}$

\begin{tabular}{|c|c|c|c|c|c|c|}
\hline \multirow[b]{3}{*}{ Date (dd/mm/yyyy) } & \multirow{3}{*}{$\begin{array}{l}\text { Macroseismic Sources } \\
\text { From DBMI11 }\end{array}$} & \multirow{3}{*}{$\begin{array}{l}\text { Seismogenetic Sources } \\
\text { From DISS03 }\end{array}$} & \multirow[b]{2}{*}{ Epicenter Intensity } & \multirow[b]{2}{*}{ Magnitude } & \multirow{2}{*}{$\frac{\text { Felt Intensity }}{\text { Catania }}$} & \multirow{2}{*}{$\begin{array}{c}\text { Felt Intensity } \\
\text { Zafferana E. }\end{array}$} \\
\hline & & & & & & \\
\hline & & & MCS & $M_{e} / M_{w}$ & MCS & MCS \\
\hline $11 / 01 / 1693$ & Eastern Sicily & ITMW087 & XI & 7.41 & $\mathrm{X}$ & $\mathrm{X}^{\mathrm{b}}$ \\
\hline $04 / 02 / 1169$ & Eastern Sicily & ITMW024 & $\mathrm{X}$ & 6.41 & $\mathrm{X}$ & $I X-X^{b}$ \\
\hline $10 / 12 / 1542$ & Siracusano & ITMW062 & $\mathrm{X}$ & 6.77 & VIII & \\
\hline $11 / 01 / 1848$ & Augusta & n.a. & VII-VIII & 5.45 & VII & $\mathrm{V}^{\mathrm{b}}$ \\
\hline $20 / 02 / 1818$ & Catanese & ITMW133 & IX-X & 6.23 & VII & VIII \\
\hline $17 / 06 / 1879$ & Etna Area & ITMW164 & VIII-IX & 4.84 & IV & VI \\
\hline $28 / 12 / 1908$ & Southern Calabria & ITMW180 & $\mathrm{XI}$ & 7.10 & VI-VII & VIII \\
\hline 08/05/1914 & Etna Area & ITMW185 & IX-X & 5.29 & $\mathrm{~V}$ & VI-VII \\
\hline 08/08/1894 & Etna Area & ITMW173 & VIII-IX & 4.84 & IV & $\mathrm{V}$ \\
\hline $15 / 10 / 1911$ & Etna Area & ITMW183 & VIII-IX & 4.84 & III & IV \\
\hline
\end{tabular}

${ }^{a}$ Equivalent magnitudes $\left(M_{e}\right)$ and moment magnitudes $\left(M_{w}\right)$ are also reported for historical and instrumental events, respectively.

${ }^{\mathrm{b}}$ Felt intensity estimated from the macroseismic field.

the macroseismic field, both the inferred sources are, indeed, located less than $60 \mathrm{~km}$ from Mount Etna (Figure 4).

[32] The southern Calabria source might be able to generate events comparable to the 1693 earthquake. Instead, the other local seismic sources, according to the historical data, are associated with events of lower levels of energy release (never reached magnitude 7), and thus have been neglected with respect to the strongest expected local seismic actions. However, "anomalous" near-field earthquakes [Barberi et al., 2004; Patanè et al., 2006], potentially able to affect the behavior of Mount Etna volcano in spite of their low magnitude [Milana et al., 2008], have been also taken into account.

\subsubsection{Seismic Scenarios}

[33] Three main scenarios can be derived from the above seismic framework (details of model constraints and seismic inputs are reported in Appendix B).

[34] 1. Strong, near-field earthquake with long return period/low probability of occurrence: Both the southern Calabria and eastern Sicily sources can be considered able to generate such an event. However, given the larger epicentral distance and the lower felt intensity at Zafferana Etnea of the 1908 "Reggio e Messina" earthquake, the 1693 "eastern Sicily" earthquake, with magnitude about 7.4 and epicentral distance 10-60 km, was chosen. The seismic input derived for this scenario, with a recurrence time of 2475 years, is characterized by a peak of ground acceleration (PGA) value of $2.3 \mathrm{~m} / \mathrm{s}^{2}$, an Arias intensity of about $0.41 \mathrm{~m} / \mathrm{s}$, and a main frequency content in the range $1-3.5 \mathrm{~Hz}$.

[35] 2. Strong, far-field earthquake with short return period/high probability of occurrence: In this regard, the worst-case for the Etnean area is related to the Aegean seismicity and can be represented by the 365 A.D. Crete earthquake (Table 2, estimated magnitude $>8$ ). An average recurrence time of 2-5 years can be considered for Aegean earthquakes with $M>6$; the reference inputs for this scenario were derived from accelerometric records, characterized by PGA values ranging $0.007-0.02 \mathrm{~m} / \mathrm{s}^{2}$, Arias intensities ranging between $2 \times 10^{-5}$ and $8 \times 10^{-5} \mathrm{~m} / \mathrm{s}$, and a main frequency content in the range $1-2.5 \mathrm{~Hz}$.

[36] 3. Low-magnitude, near-field events typified by an anomalous LP spectral content: In this case, the reference inputs were derived from accelerometric records of the 2002 LP seismic sequence [Milana et al., 2008], characterized by
PGA values of $3.5 \mathrm{~m} / \mathrm{s}^{2}$, Arias intensities of $4 \times 10^{-1} \mathrm{~m} / \mathrm{s}$, and a main frequency content in the range $0.5-2 \mathrm{~Hz}$. It is not possible to estimate a recurrence time for this seismic scenario, since earlier analogous events are not documented.

\section{Stress-Strain Numerical Modeling}

[37] Stress-strain 2-D numerical modeling by the FDM code FLAC 7.0 [ITASCA, 2011] was performed along the N130 oriented cross section of interest (Figure 2a), in order to analyze the effects of eruptive conditions, inner pressures, and seismic actions (see the above described scenarios) on Mount Etna volcano instability. The model domain is $30.5 \mathrm{~km}$ by length and $5.5 \mathrm{~km}$ by height (corresponding to an elevation from -2000 to $3500 \mathrm{~m}$ asl); a $80 \mathrm{~m} \times 80 \mathrm{~m}$ square grid was defined for the whole numerical domain as the best compromise for rigorous numerical computation of dynamic modeling and adequate extension of the investigated domain, which is focused on a specific volcano flank portion. An elastic, perfectly plastic rheological behavior was assumed and the main anisotropies of the volcanic deposits were modeled by adopting an "ubiquitous joint" constitutive law [ITASCA, 2011], according which strength parameters are distinguished for rock matrix and joints; plasticity conditions can be reached at different strain levels, thus producing a strain field which is mainly oriented along the joints. The reliability of these rheological assumptions bears on the choice of short-time transient perturbative actions, i.e., with a negligible interaction with the long-time creep deformation affecting the volcano edifice.

[38] Horizontal displacements along the lateral boundaries of the model were avoided to simulate infinite lateral confining conditions, while vertical displacements were allowed; under dynamic conditions, a transmitting boundary was applied at the base of the model and free field conditions were imposed at the lateral boundaries. Seawater hydrostatic pressures up to $\sim 1500 \mathrm{~m}$ below sea level were also modeled, relative to the present coastline (i.e., about $23 \mathrm{~km}$ from the western model boundary).

[39] The parameter values were attributed according to the different percentages of volcanic rock types that characterize the different zones of the volcano (Figure $2 b$ and Table 4 ). In more detail, the parameter values were derived based on the 


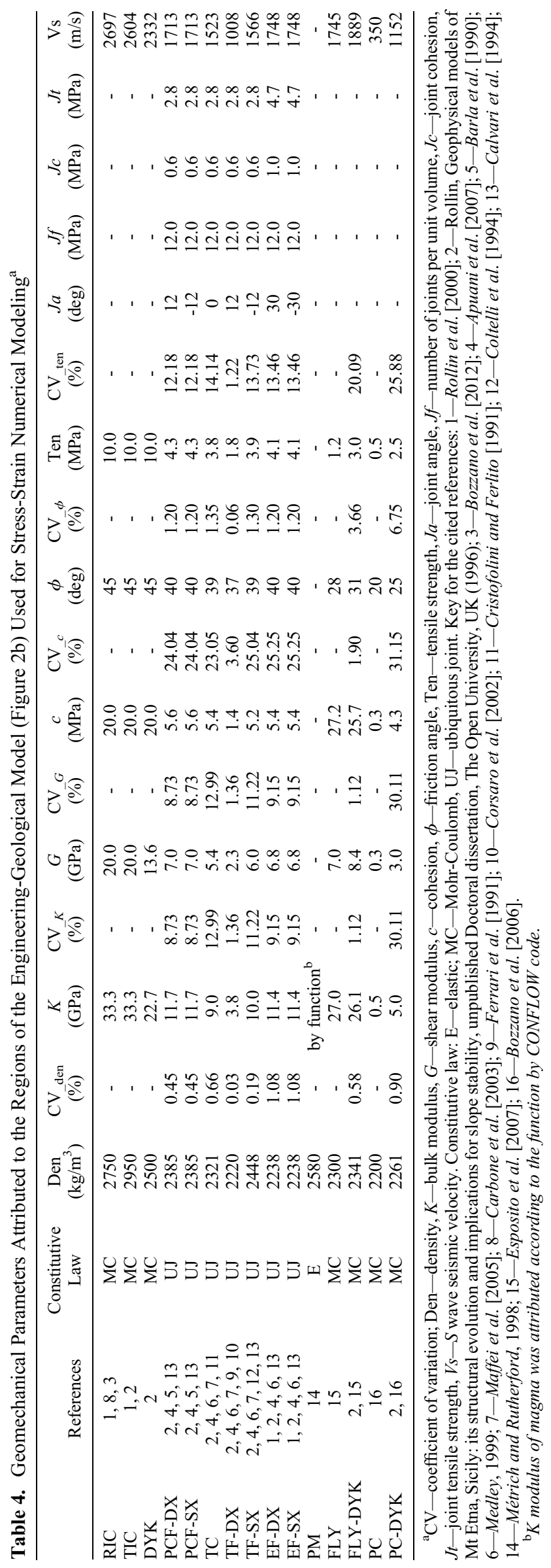

different proportions of intrusive bodies (including dikes), lava, and pyroclastics in the volcanic edifice derived from literature data (see Table 4). On these grounds, we obtain that both the Trifoglietto and the recent intrusive complexes (TIC and RIC, respectively; Figure 2b) are characterized by nearly 100 vol \% of intrusive rocks; the flanks of the Ellittico edifice and the Ellittico caldera fill show the highest amounts of lava (about 75\%); the eastern flank of the Trifoglietto paleovolcano is made up of the highest amount of pyroclastic rocks (i.e., volcanic conglomerates, breccias, coarse, and fine ash layers) [Ferrari et al., 1991; Corsaro et al., 2002]. In particular, scoria deposits attain about $25 \%$ in all zones, except for the western flank of the Trifoglietto paleovolcano where they occur limitedly $(<10 \%)$ [Cristofolini and Ferlito, 1991; Calvari et al., 1994; Coltelli et al., 1994].

[40] The basic values of the geotechnical parameters were derived by literature data from geophysical investigations, which average the in-site properties of the rock masses of the volcano. Thus, parameter values were averaged over the entire modeled pressure range of $0.1-10 \mathrm{MPa}$, without considering vertical variations as a function of depth. However, for attributing the parameter values, a spatial-depending function was adopted, which consists of a linear variation along the horizontal direction, based on the abundance (Figure 2c; data from McGuire [1982], McGuire et al. [1990], Ferrari et al. [1991], Neri et al. [1991], Calvari et al. [1994], and Coltelli et al. [1994]), average thickness, and dipping of dikes in the volcanics.

[41] Before simulating the stress-strain effects due to the inner and external actions according to the selected scenarios, an initial static equilibrium was achieved by applying a vertical gravity force (i.e., neglecting deviation from the vertical due to tidal forces). On these grounds, at-yielding conditions (i.e., corresponding to a plasticization state due to nonreversible strains) are not reached within the model domain and the stress distribution results to be strongly controlled by the topography and the geomechanical zoning of the model. Along the southeastern volcano slope, the inertial velocity vectors are not oriented toward a preferential direction, so that no landslide mechanisms result from the velocity field.

[42] The used time histories correspond to LEMA_DES multifrequential dynamic equivalent signals [Lenti and Martino, 2010], derived from the natural or synthetic accelerograms referred to the selected earthquake scenarios (Figure 5). Further details on the dynamic numerical modeling are reported in Appendix C.

\section{Results}

[43] Here we illustrate the results of numerical simulations for each of the selected scenarios. Numerical outputs were analyzed in terms of stress and strain along four vertical scan lines (V1, V2, V3, and V4; Figure 1b) monitored in the model, about $1 \mathrm{~km}$ spaced and distributed from the SEC to the Valle del Bove depression (i.e., 2-5 km from the western model boundary). In particular, the stress values were computed only along the SEC vertical scan line V1 and were obtained by subtracting the stresses resulting from each scenario to the ones resulting under initial static conditions; the resulting differential stress values $(\Delta \sigma)$ correspond to relaxation in the case of tensile values and to contraction in the case of compressive ones. 


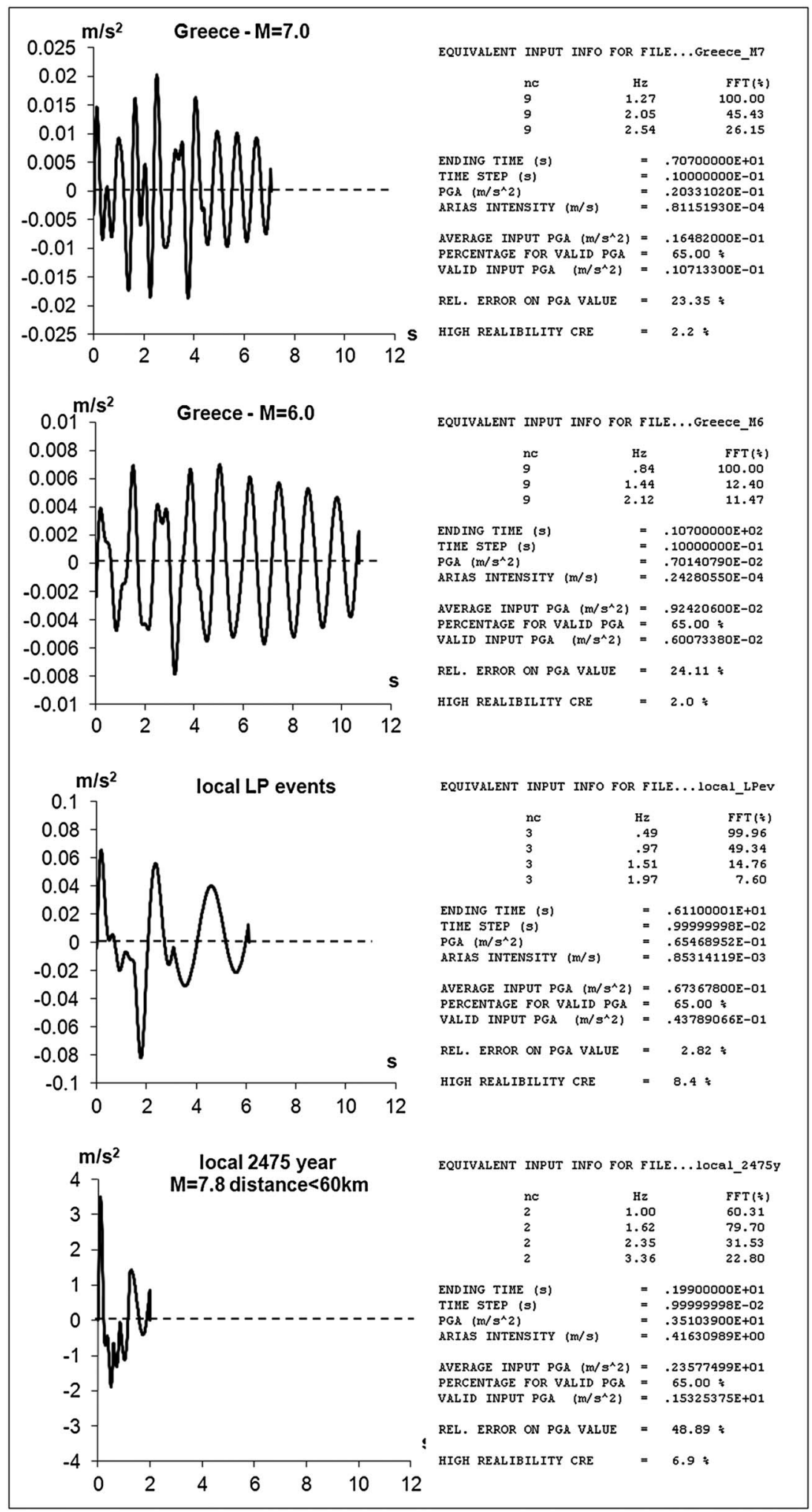

Figure 5. Equivalent inputs derived by the LEMA_DES procedure [Lenti and Martino, 2010] for the seismic scenarios modeled here and related automatic reports including the number of characteristic cycles $(\mathrm{nc})$, the characteristic frequency values $(\mathrm{Hz})$, and the percentage of each frequency contribution in the FFT. The main parameters of the equivalent accelerometric time history (ending time, time step, PGA, Arias intensity), the reference parameters for the LEMA_DES convergence procedure (average input PGA, percentage for valid PGA, valid input PGA), and the reliability of the input in terms of PGA error and convergence relative error (CRE), are also reported. 


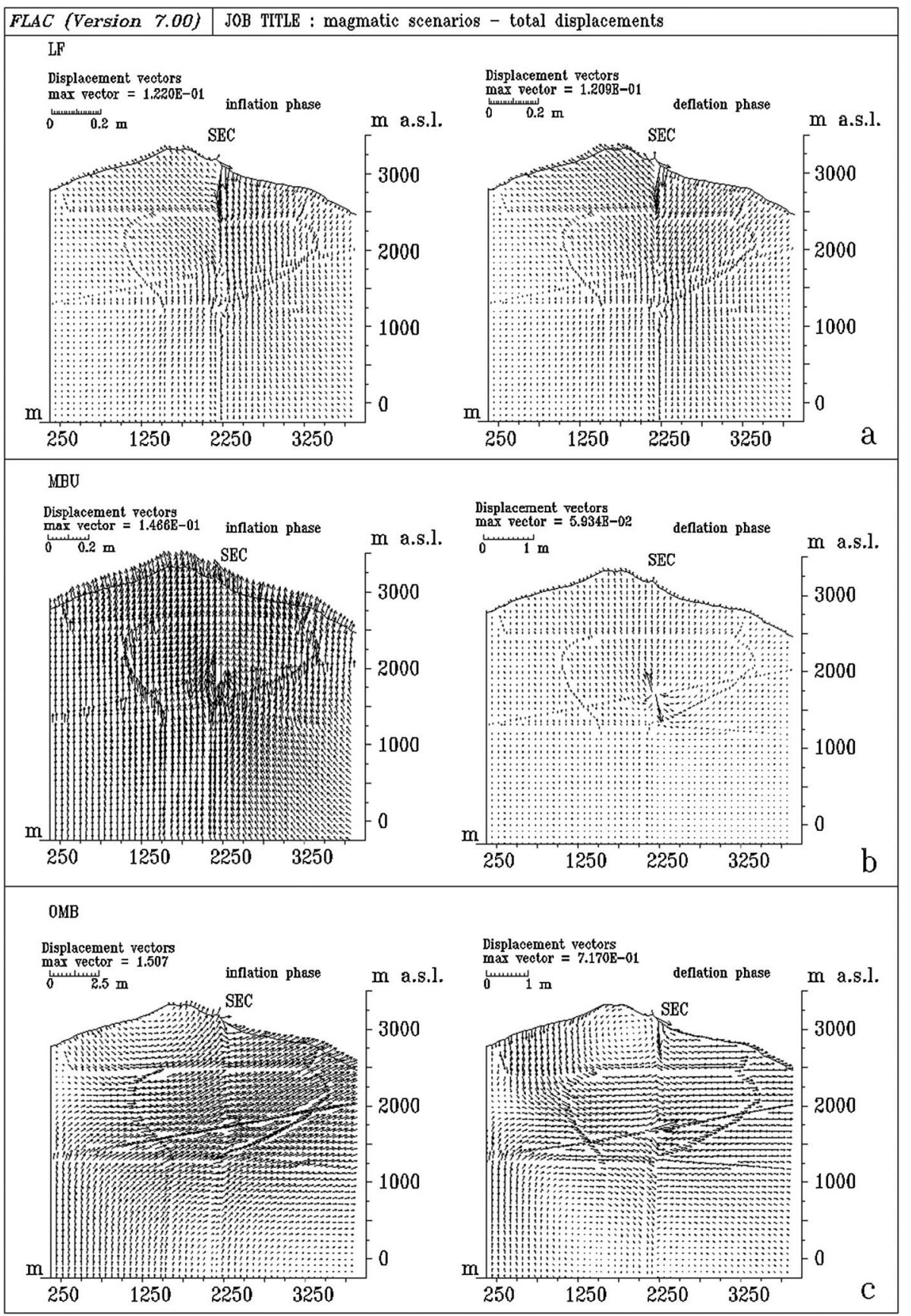

Figure 6. Outputs of the numerical model referred to the magmatic scenarios of Figure 3 ((a) LF, (b) MBU, and (c) OMB) modeled by the FDM numerical code (see text for details): vector field of the total displacements derived for the magma (left) inflation and (right) deflation phases. The sketches are zoomed in the summit part of Mount Etna and the arrays represent the total displacement vectors.

\subsection{Magmatic Scenarios}

[44] The first simulated magmatic scenario (Figure 6a) considers the stress-strain effects induced by lava fountaining during violent Strombolian activity (LF; see section 3.2). Since an isotropic behavior is assumed for the magma fill in the conduit, no directional variations of pressure are considered. The obtained $\Delta \sigma$ values along the SEC scan line show an irregular distribution (Figure 7), which fits well the input pressure distribution along the conduit; on the other hand, the resulting horizontal displacements ( $x$ disps) show a westward movement of the upper portion of the conduit (i.e., above
$1500 \mathrm{~m}$ asl), which is associated with upward vertical displacements ( $y$ disps) up to $0.08 \mathrm{~m}$ (Figure 6a). This strain field involves the SE slope of Mount Etna from the SEC down to $\sim 2500 \mathrm{~m}$ asl. The comparison between the displacement fields obtained during the inflation and deflation phases shows that the total displacements mostly correspond to permanent deformations (Figure 6a).

[45] In the simulation of vertical magma uprise below the SEC (MBU scenario in section 3.2), the pressure of about $60 \mathrm{MPa}$ is applied, since it was computed at the head of the magma dike (i.e., $\sim 1500 \mathrm{~m}$ asl), assuming an isotropic 


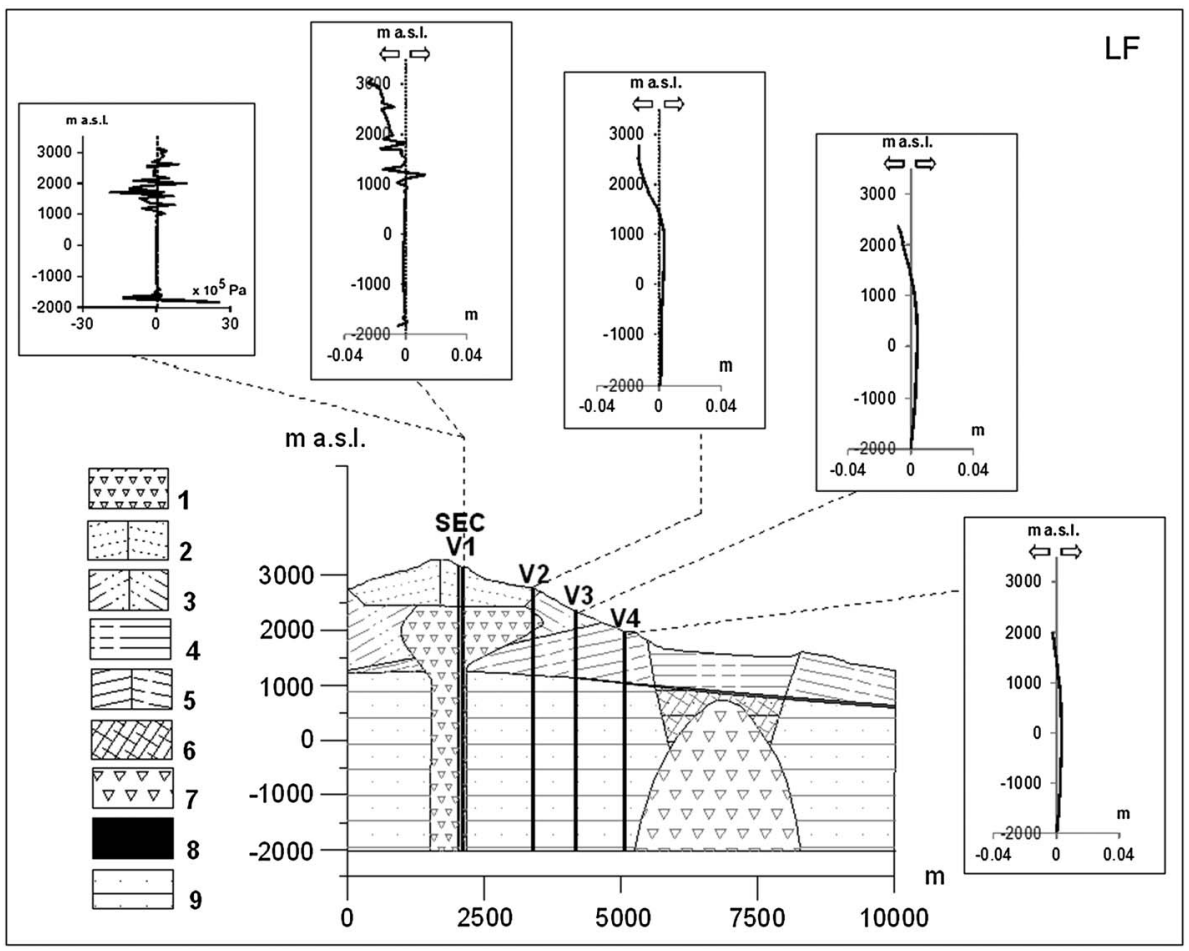

Figure 7. Model outputs for the LF magmatic scenario of Figure 3: distribution of horizontal displacement values along the vertical scan lines V1, V2, V3, and V4 (locations in Figure 1b). The vertical distribution of the stress values along V1 (corresponding to the SEC conduit) is also reported. See Figure 2 for keys to the geological legend.

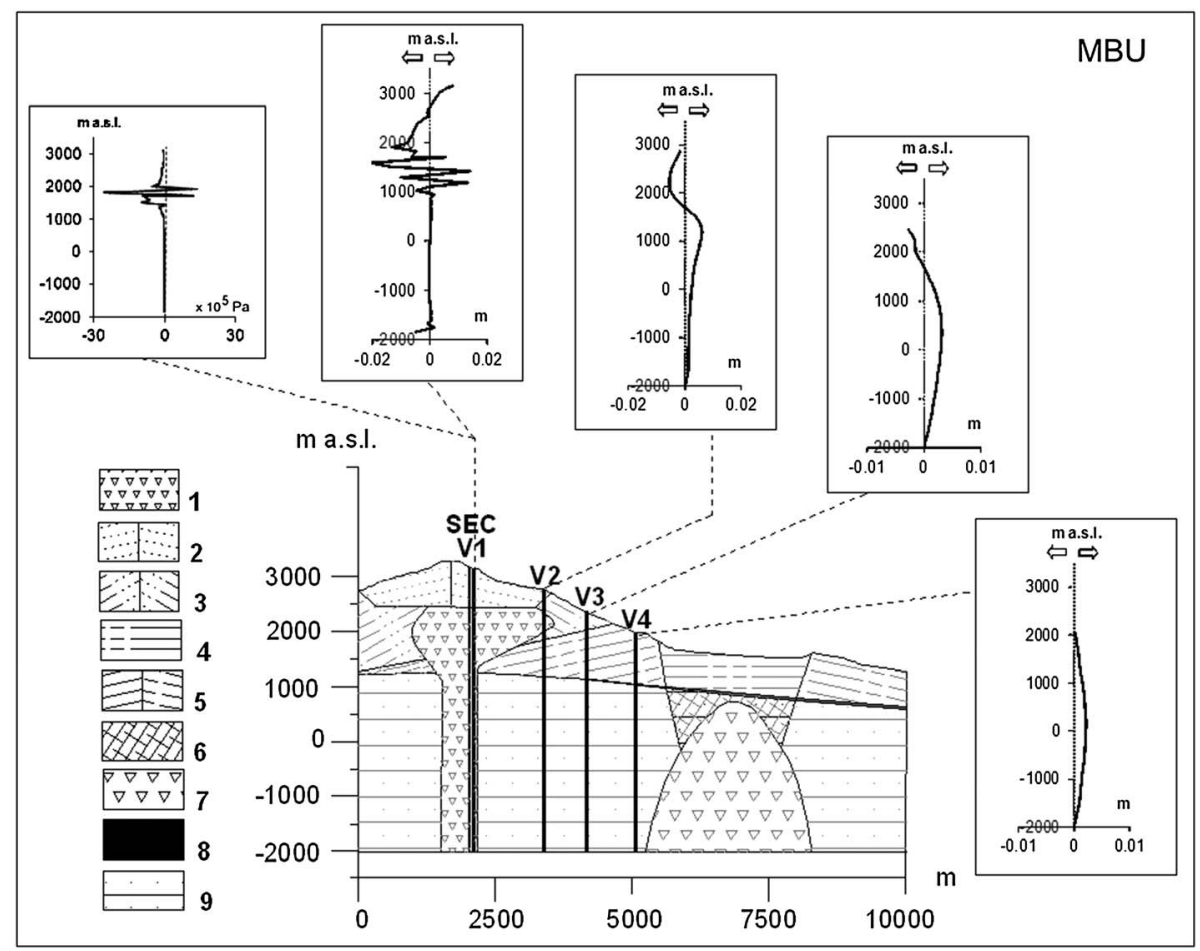

Figure 8. Model outputs for the MBU magmatic scenario of Figure 3: distribution of horizontal displacement values along the vertical scan lines V1, V2, V3, and V4 (locations in Figure 1b). The vertical distribution of the stress values along V1 (corresponding to the SEC conduit) is also reported. See Figure 2 for keys to the geological legend. 


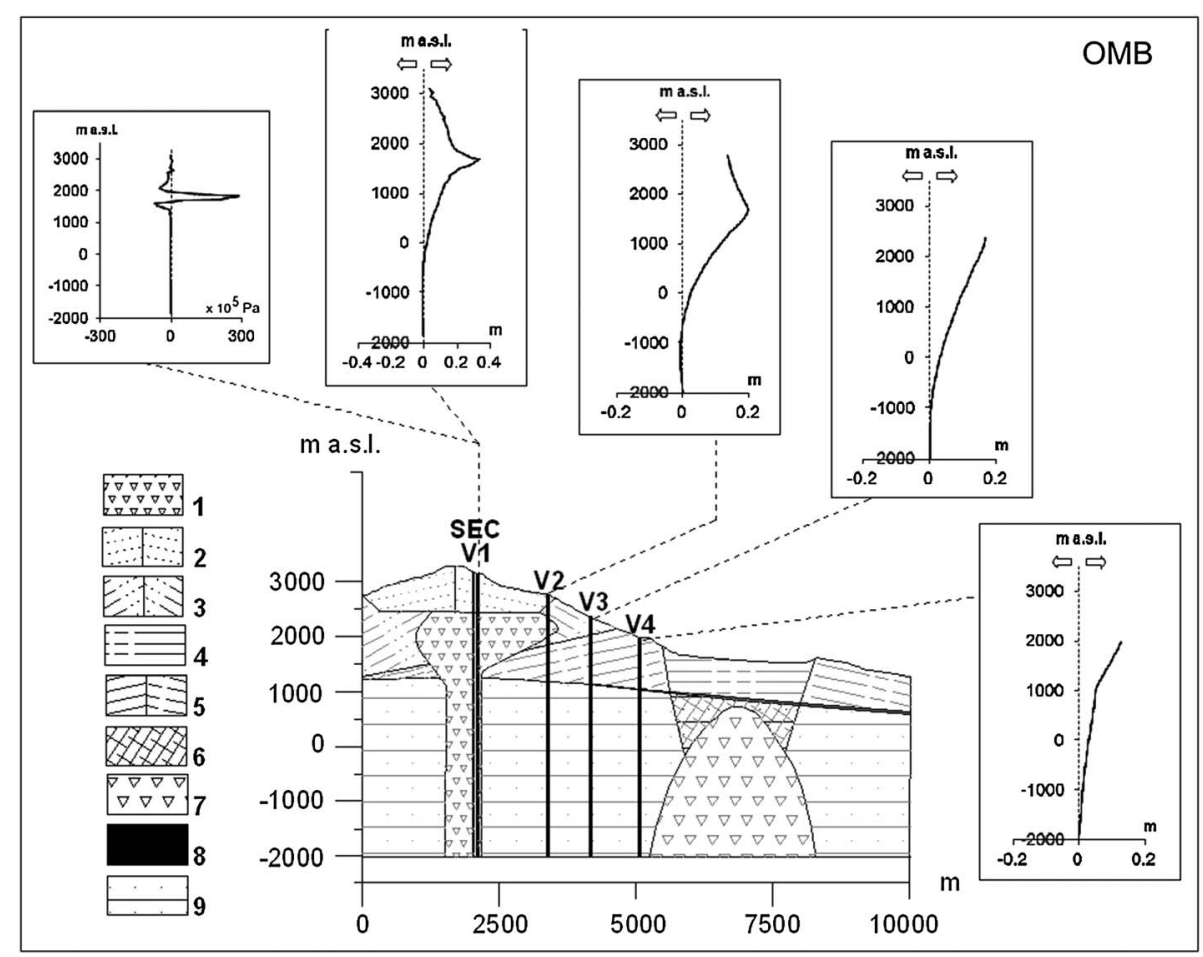

Figure 9. Model outputs for the OMB magmatic scenario of Figure 3: distribution of horizontal displacement values along the vertical scan lines V1, V2, V3, and V4 (locations in Figure 1b). The vertical distribution of the stress values along V1 (corresponding to the SEC conduit) is also reported. See Figure 2 for keys to the geological legend.

distribution (see Appendix A for more details). The resulting stress variation induced within the rock mass (Figure 8) is equal to a tensile $\Delta \sigma$ peak of $\sim 3.0 \mathrm{MPa}$ at the head of the dike and to a compressive $\Delta \sigma$ peak up to $-1.0 \mathrm{MPa}$ along the conduit walls within $\pm 500 \mathrm{~m}$ depth interval from the head of the magma dike. The resulting strain effects (Figures 6b and 8) show an irregular distribution of $x$ disps, with an intensity up to $0.03 \mathrm{~m}$, and a more regular distribution of $y$ disps, which indicate about $0.015 \mathrm{~m}$ uplift of the whole summit portion of the volcano. In this case, the comparison between the displacement fields obtained during and after the force action shows that most deformations are reversible (Figure $6 \mathrm{~b}$ ).

[46] The third magmatic scenario, the vertical to oblique dike propagation beneath the central crater area (OMB in section 3.2) also assumes isotropic pressures along the central conduit and the eruptive fissure. The obtained results (Figures $6 \mathrm{c}$ and 9) indicate a tensile $\Delta \sigma$ peak up to $30 \mathrm{MPa}$ along the conduit at about $2000 \mathrm{~m}$ asl and compressive $\Delta \sigma$ peaks up to $5 \mathrm{MPa}$ in the adjacent portion of the conduit, within a depth range of $2500-1000 \mathrm{~m}$ asl (Figure 9). This $\Delta \sigma$ distribution corresponds to the rock mass cracking under tensile conditions at the point where the vertical dike turns to oblique, driven by the main joints of the left flank of the Trifoglietto edifice, with consequent compression in the adjacent rock mass. The resulting strain field (Figure 6c) shows a remarkable concentration of eastward, mainly horizontal, displacements up to $1.5 \mathrm{~m}$, which involve the SE volcano flank from the SEC down to the Valle del Bove depression. The comparison between the displacement fields obtained during and after the force action shows that the main percentage of the total displacements (which can be related to the horizontal components) correspond to permanent deformations (Figure 6c).

\subsection{Seismic Scenarios}

[47] The simulation of a near-field $M>6$ earthquake (see scenario a in the section 3.3.2) is responsible for $\Delta \sigma$ along the conduit up to $0.6 \mathrm{MPa}$ and averagely equal to $0.3 \mathrm{MPa}$ within the elevation range $1000-3000 \mathrm{~m}$ asl. The induced $x$ disps are very similar along the reference scan lines and reach a maximum value of $0.2 \mathrm{~m}$ : Their vertical distributions show a progressive increase up to $1000 \mathrm{~m}$ asl, then the $x$ disps rate generally increases up to the topographic surface with increasing distance from the SEC (Figure 10). In this case, the resulting $y$ disps are significantly lower than the $x$ disps, as they do not exceed $0.05 \mathrm{~m}$ of uplift and they reach $0.25 \mathrm{~m}$ of settlement only along the SEC scan line, very close to the topographical surface (i.e., up to $2500 \mathrm{~m}$ asl).

[48] The modeled $M>6$ far-field earthquakes (scenario b in section 3.3.2) do not induce relevant stress-strain effects along the four scan lines, both the $x$ disps and the $y$ disps resulting lower than $2 \mathrm{~mm}$ and the $\Delta \sigma$ (both tensile and compressive) less than $10 \mathrm{kPa}$. For the input propagation of the seismic waves from the bottom of the model domain, attenuation was neglected due to the far epicentral distances and the results show a faster propagation within the intrusive body below the Trifoglietto edifice with respect to the adjacent volcanics (Figure 11).

[49] Numerical results from the modeled $M<5$ LP earthquakes (scenario $c$ in section 3.3.2), with epicenters respectively located at 2800, 7760, and 11,760 $\mathrm{m}$ from the SEC, yield very 


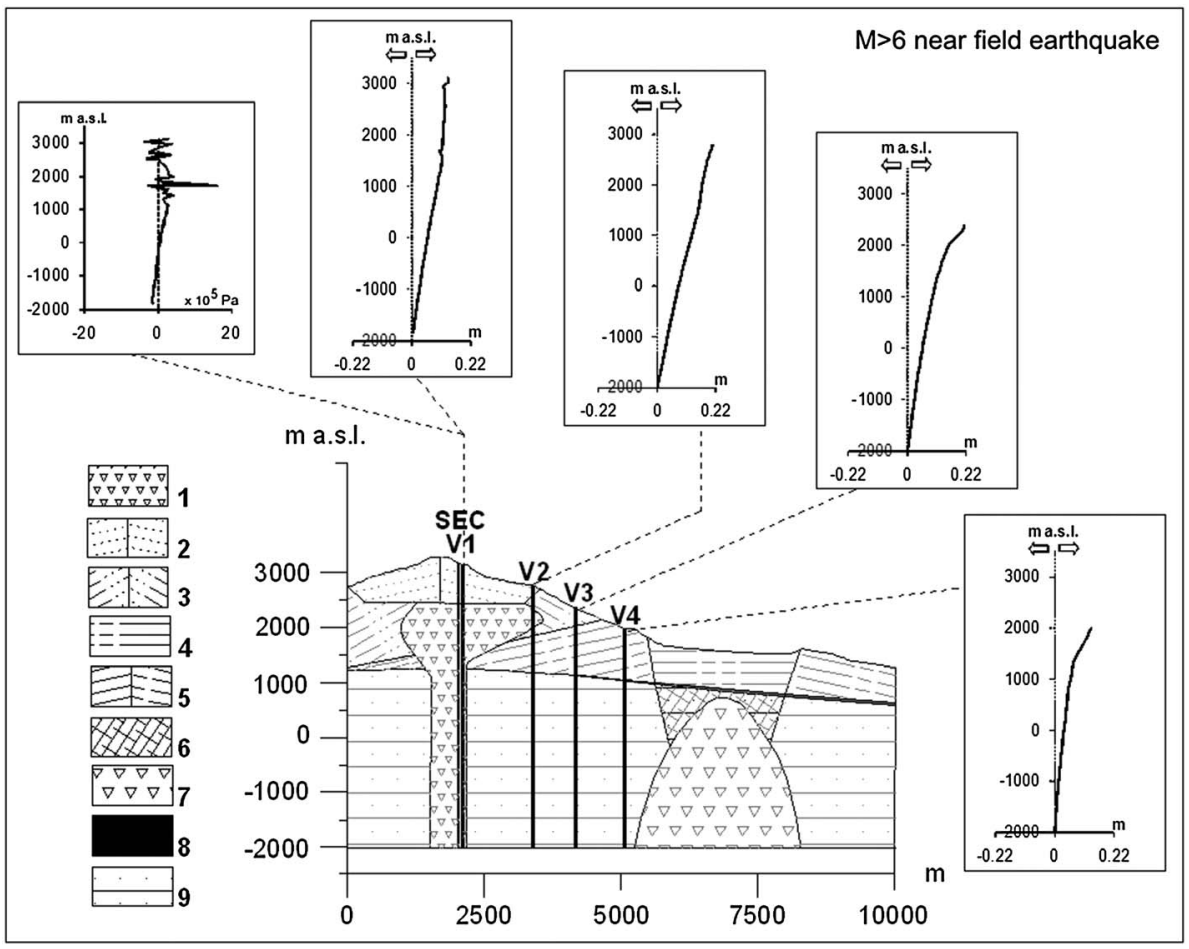

Figure 10. Outputs from numerical modeling of the $M_{w}>6$ far-field earthquake (see Figure 5 for the reference seismic input): distribution of horizontal displacement values along the vertical scan lines V1, V2, V3, and V4 (Figure 1b). The vertical distribution of the stress values along V1 (corresponding to the SEC conduit) is also reported. See Figure 2 for keys to the geological legend.

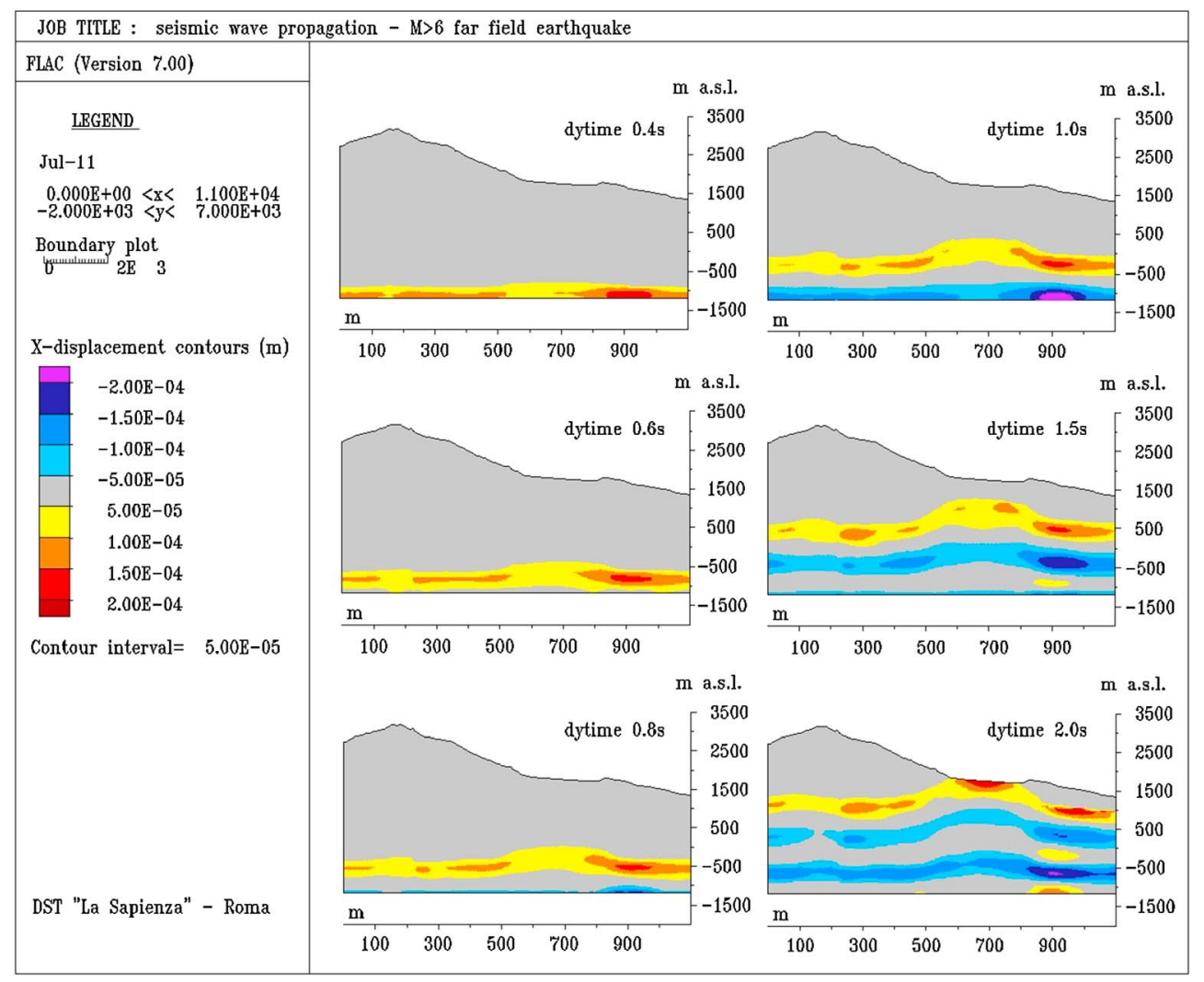

Figure 11. Horizontal displacement field resulting from numerical modeling of seismic wave propagation related to a $M_{w}>6$ far-field earthquake. 


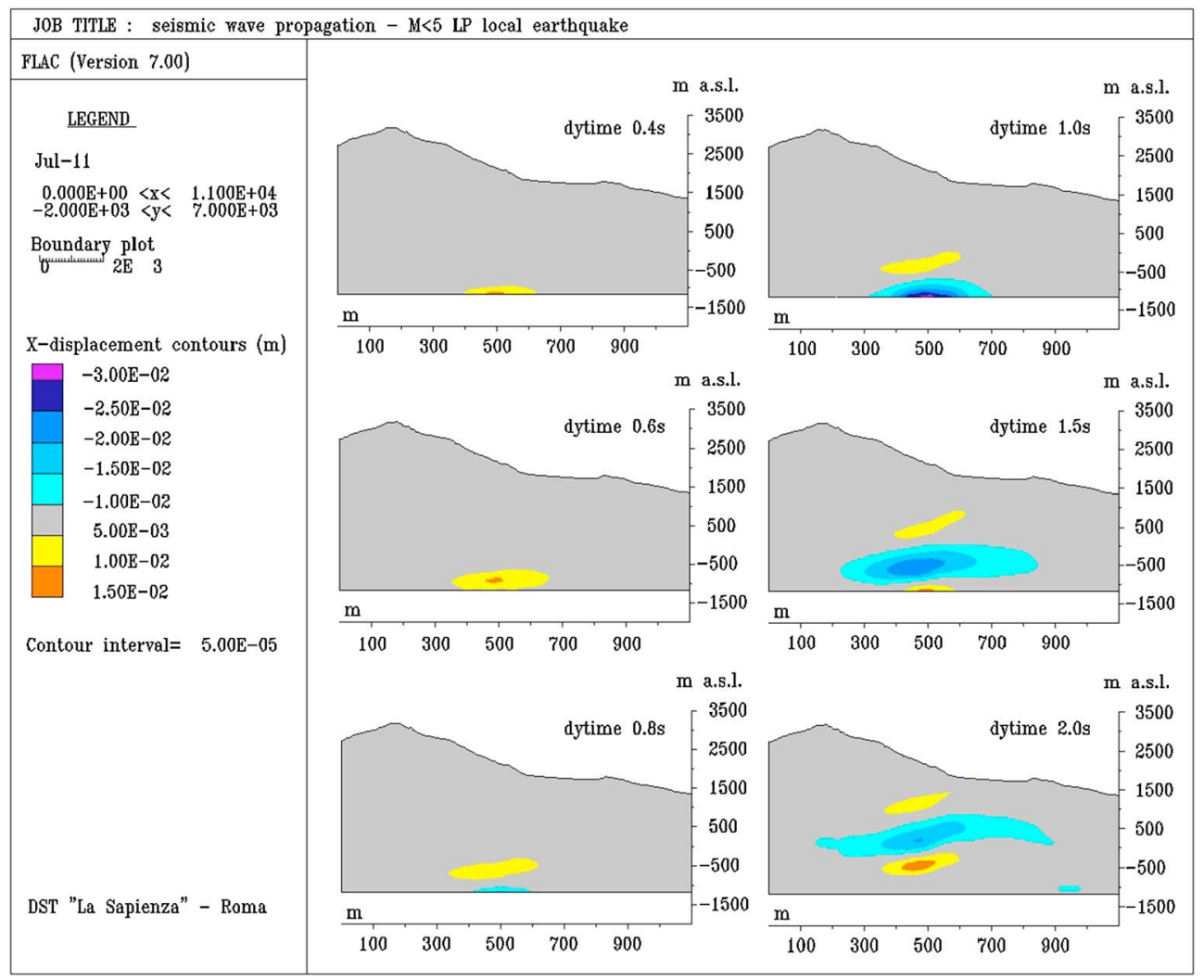

Figure 12. Horizontal displacement field resulting from numerical modeling of seismic wave propagation related to a $M_{w}<5$ local long period (LP) earthquake.

similar distributions of stress-strain effects, although their intensities considerably decrease with the increasing distance of the epicenters. In any case, the $x$ disps are significantly higher than the $y$ disps, except for the most superficial portion of the SEC, where the maximum settlement values are reached.

[50] The vertical distributions of $x$ disps along the scan lines show a progressive increase up to $1000 \mathrm{~m}$ asl; farther upward, the $x$ disps rate generally increases with increasing distance from the SEC. In particular, the LP earthquake with the nearest epicenter to the SEC induces tensile $\Delta \sigma$ along the SEC conduit in the elevation range $0-2100 \mathrm{~m}$ asl and compressive $\Delta \sigma$ upward. The maximum tensile $\Delta \sigma$ of $\sim 0.4 \mathrm{MPa}$ is reached at $\sim 1500 \mathrm{~m}$ asl, while the maximum compressive $\Delta \sigma$ of $\sim 0.7 \mathrm{MPa}$ is reached at $\sim 2500 \mathrm{~m}$ asl. The corresponding $x$ disps attain a maximum value of about $0.09 \mathrm{~m}$ within the elevation range 1000-3000 $\mathrm{m}$ asl. The LP earthquake with the most distant epicenter from the SEC induces mainly tensile $\Delta \sigma$ in the elevation range $0-2000 \mathrm{~m}$ asl along the SEC conduit and mainly compressive upward. The maximum tensile $\Delta \sigma$ of $\sim 0.35 \mathrm{MPa}$ is reached at $\sim 1500 \mathrm{~m}$ asl, while the compressive $\Delta \sigma$ does not exceed $0.2 \mathrm{MPa}$. The corresponding $x$ disps values do not exceed $0.025 \mathrm{~m}$ along the reference scan lines. The only significant vertical settlements reach $0.1 \mathrm{~m}$ toward the most superficial portion of the SEC. Finally, the LP earthquake with intermediate epicentral distance induces intermediate $\Delta \sigma$ and displacement values, with vertical distributions along the scan lines quite similar to the previous cases. Again, considering the local attenuation law [Scognamiglio et al., 2005] for the input propagation of the seismic waves from the bottom of the model, we obtained a concentrated seismic wave some hundreds of meters extending and propagating upward through the volcanics (Figure 12).

\subsection{Overview of the Numerical Results From Magmatic and Seismic Scenarios}

[51] Model results allow comparison among the different scenarios in terms of intensity and distribution of the effects induced along the SE slope of Mount Etna, particularly in the crucial sector extending from the SEC to the Valle del Bove. It appears that the modeled magmatic scenarios can be responsible for significant stress variations (both compressive and tensile) in the SEC conduit, mainly focused close to the location of the peaks of inner pressures. The induced strain fields strongly depend on the different inner pressures. The most intense $y$ disps result from the OMB scenario: Uplift values up to $10^{-1} \mathrm{~m}$ are induced along the SE volcano flank, downslope of the SEC, during the inflation phase due to low-angle dike propagation from the central conduit. Instead, the maximum settlement is related to the LF scenario and corresponds to the conduit pressure change associated with the steady state flow of a magma-gas mixture through the eruptive feeder system. Under these conditions, the SE volcano flank upslope of the SEC up to the summit craters is involved in downward $y$ disps up to $0.01 \mathrm{~m}$.

[52] Except for the OMB scenario, all the other modeled magmatic scenarios show horizontal displacements lower than vertical ones (Figure 6). In the OMB case only, the $x$ disps distributions along the monitored scan lines, as well as the resulting stress variation field, clearly highlight a failure within the SEC conduit at about $1500 \mathrm{~m}$ asl, 
Table 5. Measured Parameters (Deformations and Tilt Variations) at Mount Etna Used for Validating the Numerical Results From the Modeled Eruptive Scenarios ${ }^{\mathrm{a}}$

\begin{tabular}{|c|c|c|c|c|}
\hline Eruptive Scenario & Modeled Magmatic Scenario & Measured Parameters & Site of Measurements & Reference \\
\hline 2000 SEC lava fountaining & LF & High precision tilt observation & $\begin{array}{c}\text { PDN Pizzi } \\
\text { Deneri Station }\end{array}$ & Bonaccorso [2006] \\
\hline $\begin{array}{l}\text { Magma batch upraising below the } \\
\text { Southeast Crater 1991-1993 eruption }\end{array}$ & MBU & $\begin{array}{l}\text { Maximum vertical displacement } \\
\text { from InSAR data }\end{array}$ & Summit area & Lundgren et al. [2003] \\
\hline $\begin{array}{l}\text { Magma batch upraising below the } \\
\text { Southeast Crater 1991-1993 eruption }\end{array}$ & MBU & High-precision tilt observation & CDV station & Bonaccorso [2006] \\
\hline 2001 eruption & OMB & $\begin{array}{c}\text { GPS measurements of horizontal } \\
\text { displacement }\end{array}$ & $\begin{array}{l}5 \mathrm{~km} \text { downslope } \\
\text { to the SEC }\end{array}$ & Bonforte et al. [2004] \\
\hline 2001 eruption & OMB & High precision tilt observation & $\begin{array}{l}\text { PDN Pizzi Deneri } \\
\text { Station }\end{array}$ & Bonaccorso [2006] \\
\hline 2001 eruption & $\mathrm{OMB}$ & $\begin{array}{c}\text { GPS measurements of horizontal } \\
\text { displacement }\end{array}$ & EFAR station & $\begin{array}{l}\text { Bonaccorso } \\
\text { et al. }[2002]\end{array}$ \\
\hline
\end{tabular}

${ }^{\text {a }}$ The locations of measurement stations are reported in Figure 1a.

consistent with the opening of eruptive fissures along the SE volcano slope.

[53] On the other hand, all the seismic scenarios mainly induce $x$ disps involving the whole portion of the SE flank, downslope of the SEC to the Valle del Bove. The main output displacements, up to some tens of centimeters, result from a high-magnitude, near-field earthquake. Since $x$ disps are up to 1 order of magnitude higher than $y$ disps, the slope portion from the SEC to the Valle del Bove is involved in a mainly translational mechanism, which induces a tensile $\Delta \sigma$ within the SEC conduit between 3000 and $1000 \mathrm{~m}$ asl.

[54] No significant stress-strain effects are evidenced by simulations of high-magnitude far earthquakes from the eastern Mediterranean area and local LP seismic events with epicenters $>7 \mathrm{~km}$ from the SEC. Conversely, closer LP events reveal a significant stress field variation in the SEC conduit, consisting of a tensile $\Delta \sigma$ up to $2000 \mathrm{~m}$ asl, and to a mainly compressive $\Delta \sigma$ upward. Also in the latter case, the comparison of horizontal versus vertical displacements points out mainly translational, downslope movements of the SE volcano flank. In general, all the modeled earthquake scenarios induce increasing $x$ disps rates from the SEC toward the Valle del Bove, thus indicating a ductile deformation of the slope portion under consideration, rather than rigid-block sliding.

[55] To quantify the long term stress-strain cumulative effects of strong near-field earthquakes (which represent the most intense seismic actions) on the Mount Etna summit area, the seismic inputs (considered for a return time of $\sim 2500$ yrs) were repeatedly applied (25 times). This numerical experiment does not produce major flank instability, besides a $2.5 \%$ strain in the eastern summit area.

[56] Finally, in order to combine the most intense seismic actions with the most critical state of the volcanic system, the near-field $M_{w}>7$ and the LP $M_{w}<5$ seismic inputs were applied concomitant to a magmatic inflation phase (MBU scenario). Model output yields a maximum decompression of $7.0 \times 10^{7} \mathrm{~Pa}$ in the magma conduit, which is mainly concentrated at a depth of 1500 to $2000 \mathrm{~m}$ asl and is not capable to induce a major flank instability. However, the emplacement of an extensive, shallow magma body (e.g., a cryptodome) may produce flank instability eventually leading to sector collapse, inducing magma decompression in the order of $10^{7} \mathrm{~Pa}$, as occurred at many volcanoes [Guest et al., 1984] and possibly at Mount Etna in the past [Coltelli et al., 1998].

\subsection{Validation of the Numerical Model}

[57] To validate the numerical model, we evaluated the consistency of the results from the different magmatic scenarios with recent data from the monitoring system collected during corresponding volcanic activities at Mount Etna (Table 5). Concerning the LF scenario, the deformations obtained from the numerical simulation of steady state magma-gas flow at SEC were compared to available high-precision tilt observations during paroxysmal activity [Bonaccorso, 2006]. From model results, the total displacements show a horizontal component up to $2 \mathrm{~cm}$ and counterslope orientation (Figure 6a), which well fit the radial strains on the order of $\sim 1 \mu$ strain (radial orientation toward the summit craters), measured within $5 \mathrm{~km}$ from the summit area during the 22 July 22 1998 paroxysmal eruption from one of the summit craters [Bonaccorso, 2006].

[58] Also, model outputs from the MBU scenario are broadly consistent with the horizontal displacements on the order of a few centimeters obtained by GPS measurements along the eastern flank, $5 \mathrm{~km}$ downslope of the summit craters, during the 2001 eruption [Bonaccorso et al., 2002; Bonforte et al., 2004; Figure 6b].

[59] Finally, model results from the OMB scenario were compared to the maximum vertical displacements available from InSAR measurements [Lundgren et al., 2003], which show a volcano deflation of $10 \mathrm{~cm}$ following the 19911993 eruption, likely of the order of the inflation phase prior to the eruption. Again, the modeled strain field is in good agreement with monitoring data: The modeled vertical components of the displacements during the inflation phase were almost completely recovered by the volcano edifice after the deflation phase (Figure 6c). Numerical results show that deformation mainly affected the Mount Etna summit area extending to the western rim of the Valle del Bove, up to some $10^{6} \mathrm{~m}^{3} / \mathrm{m}$ over some kilometers laterally, consistent with the measured displacement fields.

\section{Discussion}

[60] Here we analyze stress-strain effects from the above modeled external (e.g., tidal and seismic) actions in respect to the expected critical states of the Mount Etna volcanic 


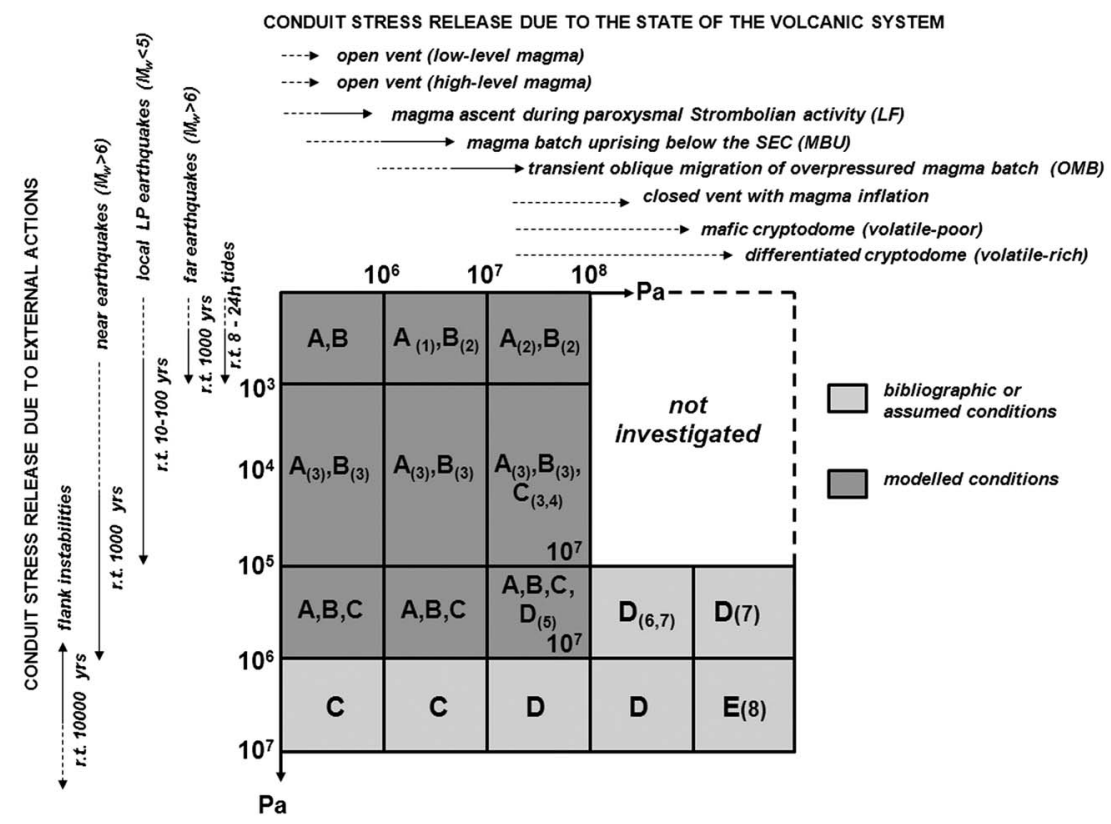

Figure 13. Conceptual chart reporting the stress release in the magma conduit as an effect of the stress associated to external actions concomitant to the different states of the volcano (see text for details). Keys to the volcano-tectonic activities: (A) minor effusive eruption; (B) paroxysmal lava fountaining; (C) major effusive flank eruption; (D) sub-Plinian to Plinian, and pyroclastic flow-forming eruption with associated caldera collapse; (E) volcano sector collapse. Keys to the references which report specific volcanotectonic activities at Mount Etna: (1) Patanè et al. [1994]; (2) Sottili et al. [2007]; (3) Milana et al. [2008] and Walter et al. [2009]; (4) Corsaro et al. [1996], Crisci et al. [2003]; (5) Corsaro and Pompilio [2004]; (6) Duncan [1976] and De Rita et al. [1991]; (7) Giordano and Dingwell [2003] and Métrich et al. [2004]; (8) Guest et al. [1984] and McGuire et al. [1990].

system. Possible scenarios of combined inner (magmatic) and external forcing are also discussed to provide a hazard overview on the flank instability that may affect the SE slope of Mount Etna.

[61] Our results point out that significant deformations can be expected in case of high-magnitude, near-field earthquakes, as well as local LP seismic events with epicenters nearby the SEC. In these cases, the resulting displacement values are similar to those from the heaviest intrusive scenario, the injection of an oblique dike (OMB). However, all the here considered seismic scenarios are responsible for mainly horizontal deformations that affect the whole volcanic edifice, while the intrusive scenarios are responsible for mainly concentrated displacements involving the upper portion of the volcano (>1000 $\mathrm{m}$ asl).

[62] Since significant permanent deformations may affect the volcano due to inner and external forcings, the cumulative effects due to repeated actions could evolve toward large deformations and/or failure conditions. Specifically, concerning the decompression along the conduit $\left(\Delta P_{m}\right)$ caused by external actions, we note that (1) the $\Delta P_{m}$ induced by Earth tides [Sottili et al., 2007] and high-magnitude far-field earthquakes are on the order of $10^{3} \mathrm{~Pa}$; (2) the $\Delta P_{m}$ induced by local, LP lowmagnitude seismic events is on the order of $10^{5} \mathrm{~Pa}$; and (3) the $\Delta P_{m}$ induced by high-magnitude near-field earthquakes is on the order of $10^{6} \mathrm{~Pa}$.

[63] Previous studies concluded that tidally induced $\Delta P_{m}$ may act as a concurrent trigger for violent lava fountaining at SEC [Sottili et al., 2007] and for persistent Strombolian activity [Sottili and Palladino, 2012] on the condition that the magma system is close to a critical state. Walter et al. [2009] discussed the trigger role of major earthquakes on volcano-tectonic events in the southern Tyrrhenian area, in light of the 6 September $2002 M_{w}=5.9$ Palermo earthquake. The succeeding volcanic unrest that occurred within an area of $150 \mathrm{~km}$, at Stromboli, Panarea, and Mount Etna (onset of the major 2002-2003 eruption on 26 October 2002), was considered a possible consequence of either a general geodynamic reorganization of the southern Tyrrhenian area and/or transient changes in the magmatic and hydrothermal systems of these volcanoes. In light of our numerical results and the occurrence of a local seismic swarm including unusual LP events [Milana et al., 2008] concomitant to the Mount Etna volcanic unrest on 27-29 October 2002, we infer that the decompression induced by LP events may have led the magma feeder system toward a critical state, thus favoring the eruption onset.

[64] With regard to the maximum expected decompression induced by external actions, the only documented $M>7$ near-field earthquake (1693 eastern Sicily) does not seem to have affected the eruptive behavior at Mount Etna. However, at that time, the major 1669 eruption might have lowered the eruptability of the volcanic system. Since the recurrence time of both the above reported major seismic and volcanic events is on the order of $10^{2}-10^{3}$ years, it follows that their near-synchronous occurrence is quite rare. Our numerical model suggests that a near-field high-magnitude event cannot lead to failure conditions of the volcano flank, 
even if it is repeatedly applied to simulate a $10^{4}$ years time interval (i.e., about 20 times longer than the recurrence period of $\sim 2500$ years).

[65] Figure 13 provides a conceptual overview of model results, also in light of previous studies, where the conduit stress release is reported as a combined effect of the state of the volcanic system and of external forcing. In Figure 13, the field of "modeled conditions" is separated from the "bibliographic" and "not investigated" ones.

[66] For increasing critical conditions, the state of the volcanic system ranges from an open vent with low level of magma to the emplacement of a differentiated, volatile-rich cryptodome, through the above-modeled scenarios (magma ascent during paroxysmal Strombolian activity, vertical magma dike below the SEC, and transient migration of an overpressured oblique magma dike). Concerning the external actions, flank instabilities themselves can be considered as responsible for stress release within the conduit. Each level of stress release implies a specific volcano-tectonic response, ranging in intensity from a minor effusive eruption to catastrophic sector collapse, i.e., covering the full range of activities documented or inferred at Mount Etna from literature data.

[67] For a lack of external actions, the volcanic system in a low-critical state is documented to reach the energetic lava fountaining level. The maximum effects induced by external actions, combined with low critical conditions of the volcanic system, may determine a major effusive flank eruption. In this regard, the minimum conditions required to achieve a major effusive eruption imply the uprise of a magma body coupled to local LP earthquakes.

[68] If we consider the coupling of external actions to increasing critical states of the volcanic system, the inferred worst-case scenario would be the result of the combined effects of the emplacement of a differentiated, volatile-rich cryptodome and volcano sector collapse. In this regard, experimental and volcanological studies [Coltelli et al., 1998; Giordano and Dingwell, 2003] suggest that the unusually explosive behavior of low-viscosity Etnean magmas feeding sub-Plinian, Plinian, and pyroclastic flow eruptions may be explained by the sudden drop of lithostatic pressure due to sector collapse episodes. Such eruption intensities, documented to have occurred several times in the past, with recurrence times on the order of $10^{3}$ years [Duncan, 1976; De Rita et al., 1991; Coltelli et al., 1998; Corsaro and Pompilio, 2004], may be also triggered by the superposition of a near-field earthquake $\left(M_{w}>6\right)$ to transient, oblique migration of overpressured magma batch (OMB).

[69] Finally, a challenging aspect of future modeling of flank instability at Mount Etna would be analyzing long-lasting, low-hazard stress-strain scenarios applied on $10^{2}$ year timescale (i.e., the "not investigated" field in Figure 13), by taking into account the time dependence of rock mass rheology (i.e., creep behavior), as well as the changes in the local thermal flow (e.g., due to the emplacement of magma bodies).

\section{Conclusions}

[70] Numerical modeling of Mount Etna flank instability points out relevant cause-and-effect interactions among internal (magmatic) and external (tidal, seismic) actions and volcano-tectonic effects, strongly dependent on the state of volcanic system. Specifically, the most significant strain effects of external forcing appear to be related to high-magnitude near-field earthquakes, with expected return time of $\sim 10^{3}$ years. Concerning the internal dynamics of the volcano, the most significant effects are due to the inner pressure changes induced by transient, oblique migration of overpressured magma batch. The modeled displacement field (characterized by maximum displacements on the order of tens of centimeters) indicates that the Mount Etna summit area, up to some $10^{6} \mathrm{~m}^{3} / \mathrm{m}$ over some kilometers laterally, is mainly involved. The above scenarios may lead to stress releases of $10^{6} \mathrm{~Pa}$ and $10^{7} \mathrm{~Pa}$, respectively, which affect a limited portion of the magmatic conduit $(1500$ $2000 \mathrm{~m}$ asl), thus favoring major effusive flank eruptions. When combined, the two actions may even lead to subPlinian to Plinian eruptions, as occurred repeatedly in the past.

[71] Numerical results show that flank collapse should not be expected by applying, either individually or combined, the aforementioned actions, consistent with geovolcanological reconstructions [e.g., Calvari et al., 2004]. We infer that the worst-case scenario, the collapse of the southern-eastern volcano flank, would require the emplacement of cryptodomes concomitant to major slope instabilities.

[72] In conclusion, the here presented model approach provides a reference framework for a well-constrained hazard assessment at Mount Etna and analogous volcanic systems undergoing a variety of destabilizing processes, including inner pressures and external actions.

\section{Appendix A: Constraints to the Magmatic Scenarios}

A1. Petrology of the Paroxysmal Lava Fountaining (LF) Feeder Magma at the Southeast Crater

[73] Table A1 reports the feeder magma composition (normalized to 100 on a $\mathrm{H}_{2} \mathrm{O}$-free basis, from Métrich and Rutherford [1998]) of paroxysmal lava fountaining (LF) at the Southeast Crater used as input parameter for numerical simulations through CONFLOW code [Mastin and Ghiorso, 2000]. Crystal content (up to 32\%) and magma density (from 2.50 to $2.65 \mathrm{~g} / \mathrm{cm}^{3}$ ) are calculated through the MELTS code for water contents ranging $2.0-3.5 \mathrm{wt} \%, P$ from 40 to $80 \mathrm{MPa}$ and $T$ from 1060 to $1085^{\circ} \mathrm{C}$.

\section{A2. Transient, Oblique Migration of Overpressured Magma Batches (OMB)}

[74] The static magmatic overpressure $\Delta P$ induced by the upward migration of a dike depends on the difference between the country-rock density $\rho_{r}$ and the magma density $\rho_{m}$. At a certain vertical distance, $h$, from the magma reservoir, the static magmatic overpressure $\Delta P$ is given by [Gudmundsson, 1999]

$$
\Delta P=p_{e}+\left(\rho_{r}-\rho_{m}\right) g h+\Delta \sigma
$$

where $g$ is the acceleration due to gravity and $p_{e}$ is the magmatic overpressure (i.e., in excess of the lithostatic pressure before the dike injection); for Mount Etna numerical modeling, the input parameter $\Delta P$ was calculated by assuming $\rho_{r}=2750 \mathrm{~kg} \mathrm{~m}^{-3}$ at a depth $h=1600 \mathrm{~m}$ below the SEC. From magma composition reported in Table A1, a magma density $\rho_{m}=1925 \mathrm{~kg} \mathrm{~m}^{-3}$ was calculated, by also considering the effects of volatile oversaturation, through CONFLOW code [Mastin and Ghiorso, 2000]. The values of $\Delta \sigma=\sigma_{v}-\sigma_{h}$, i.e., the difference between the vertical and the horizontal stress, were computed at the tip of the dike under a gravitational static equilibrium at Mount Etna, using the below described stress-strain numerical model (see section 4). 
Table A1. Composition of Glasses of Paroxysmal Lava Fountaining (LF) Products at the Southeast Crater (Normalized to 100 on a $\mathrm{H}_{2} \mathrm{O}$ Free Basis, From Métrich and Rutherford [1998])

\begin{tabular}{lc}
\hline Oxides & Weight percent \\
\hline $\mathrm{SiO}_{2}$ & 47.72 \\
$\mathrm{TiO}_{2}$ & 1.75 \\
$\mathrm{Al}_{2} \mathrm{O}_{3}$ & 17.25 \\
$\mathrm{Fe}_{2} \mathrm{O}_{3}$ & 6.97 \\
$\mathrm{FeO}$ & 3.93 \\
$\mathrm{MnO}$ & 0.21 \\
$\mathrm{MgO}$ & 6.15 \\
$\mathrm{CaO}$ & 10.11 \\
$\mathrm{Na}$ & 3.62 \\
$\mathrm{~K}_{2} \mathrm{O}$ & 1.91 \\
$\mathrm{P}_{2} \mathrm{O}_{5}$ & 0.38 \\
$\mathrm{Total}$ & 100.00 \\
\hline
\end{tabular}

\section{Appendix B: Constraints to the Seismic Scenarios}

\section{B1. A Strong, Near-Field Earthquake With a Long Return Period/Low Probability of Occurrence}

[75] Since no instrumental records are obviously available for the 1693 "eastern Sicily" earthquake, the reference time history was obtained by searching both the Consortium of Organizations for Strong-Motion Observation Systems website (http://db.cosmos-eq.org) and the European StrongMotion Database [Ambraseys et al., 2000], with selection parameters $M>7.0$ and epicentral distance lower than $60 \mathrm{~km}$. The response spectra of the selected records were compared with a "target" shape representative of the local expected spectral response, calculated at Zafferana Etnea from the uniform hazard spectra with a 2475 year recurrence, available for the whole Italian territory on a $5 \mathrm{~km}$ wide mesh (INGVDPC S1-Project website https: Ilesse1.mi.ingv.it). The best likeness with the target shape was observed for the 16 September 1978, Tabas, Iran, earthquake $\left(M_{s} 7.33\right)$, recorded at Dayhook station (epicentral/fault distance $11 \mathrm{~km}$ ). The selected time histories referred to the horizontal components were than scaled to the peak ground acceleration (PGA) value which has a $5 \%$ probability of being exceeded in 50 years (i.e., recurrence of 2475 years) at Zafferana Etnea (INGV-DPC S1-Project website https:|lesse1.mi.ingv.it). The occurrence of a seismic sequence was not taken into account, since this chance is not supported by the available historical data. Since this event represents the strongest expected one, here we consider a return time of 2475 years.

\section{B2. A Strong, Far-Field Earthquake With a Short Return Period/High Probability of Occurrence}

[76] It was chosen to model the 365 A.D. Crete earthquake (estimated magnitude $>8$ ) from the available strong motion records of recent Aegean earthquakes, rather than trying to obtain a representative time history through the approach followed for the 1693 eastern Sicily event. In particular, the records of the 8 January 2006 earthquake $\left(M_{w}=6.7\right)$ obtained at the stations of Caltagirone (CLG) and Castel di Iudica (CDI) of the RAN (http://itaca.mi.ingv.it/ItacaNet/) and the 6 January 2008 earthquake $\left(M_{w}=6.1\right)$ obtained only at the station CLG were taken into account. The negligible difference between the characteristic parameters of the recorded 6 and 7 magnitude earthquakes, allows to refer similar features also to a 8 magnitude far-field earthquake. On the basis of the online NGDC Significant Earthquakes Database (http://earthquake.usgs.gov/), an average recurrence time of 5 years was estimated for Aegean earthquakes with $M>6$; having observed a low level of completeness, this estimate was obtained from the records related to the last 100 years accounted by the database (1894-1994). However, the frequency of occurrence of the considered events might be still underestimated, since data from a more recent USGS online catalogue (USGS/ NEIC http://earthquake.usgs.gov) point out an average recurrence time of about 2 years over the last 40 years.

\section{B3. Low-Magnitude, Near-Field Events Typified by an Anomalous Long-Period (LP) Spectral Content}

[77] Between 26 and 29 October 2002, the Etnean area was intensely struck by a seismic swarm of long-period events, widely felt by the population in a large portion of eastern Sicily, from Messina to Siracusa. This seismic swarm consisted of some hundred events in the first 4 days of activity and was recorded until early 2003. The earthquakes were located in two sectors of Mount Etna [Barberi et al., 2004; Patanè et al., 2006]: A first group of epicenters was located in the east-northeastern part of the volcano, reaching a maximum $M_{L}$ of 4.6 on 27 October, while a second group that occurred after 28 October 2002 was located in the southeastern flank, close to the town of Zafferana Etnea, and culminated with the $M_{L} 4.4$ earthquake on 29 October 2002. The seismic swarm coincided with the reactivation of the eruptive fracture system originated by the 2001 eruption. In spite of its small local magnitude, the shock caused significant damage to many buildings, including reinforced concrete ones (VIII EMS intensity scale, see Grunthal [1998]), in an area that extends for about $4 \mathrm{~km}$ in a NNW-SSE direction centered around the villages of Santa Venerina and Guardia (DBMI11 catalogue) [Milana et al., 2008]. Events of this kind are recurrent in the area and their relevant effects are generally related to shallow sources; another reason for the unexpected level of damage was however highlighted [Milana et al., 2008] by the 2002 records, which show an anomalously strong low-frequency content and able to produce large ground displacements and long (up to $20 \mathrm{~s}$ ) durations of shaking. The accelerograms and the broadband seismograms referred to these events, which have been recorded so far, demonstrate that an anomalously strong low-frequency $(0.1<f<1 \mathrm{~Hz})$ radiation deviates from the conventional Brune [1970] spectral scaling [Milana et al., 2008]. As already observed in other volcanic areas [Jousset and Douglas, 2007, and references therein], the seismograms referred to these events are characterized by an enrichment of long-period (1-10 s) motions, compared to tectonic earthquakes of equivalent magnitude. Therefore, they cause large ground displacements and long $(\approx 20 \mathrm{~s})$ durations of shaking, while the integration of the related digital accelerograms yields a maximum peak ground displacement as large as $1.8 \mathrm{~cm}$ at a distance of $18 \mathrm{~km}$. In order to evaluate possible effects of these LP events on the Mount Etna flank instability, the accelerograms of the 27 October $2002\left(M_{L}=4.6\right)$ and 29 October $2002\left(M_{L}=4.4\right)$ events, recorded by the RAN at Catania (CAT) and Bronte (BNT) stations (see zoomed window in Figure 4) and archived in the ITACA online database, were taken into account. According to the recorded strong motions of the 2002 seismic swarm, the epicenters of the LP events can be located between the SEC and Zafferana Etnea. The widespread, relevant, and well-documented damage effects 
suggest to evaluate the possible influence of these near-field LP events on the slope instability of the eastern volcano flank, even though it is not possible to estimate their recurrence time, since the 2002 swarm was the first one to be recorded.

\section{Appendix C: Methods for the Dynamic Numerical Modeling}

[78] A numerical analysis of local seismic response was performed by the FDM code FLAC 7.0 in order to quantify the variations of the ground motion in the volcano model due to seismic actions mainly related to the geological setting. On purpose, a dynamic configuration was adopted and a delta-like Gabor function $(G(t))$ was applied in the form of a vertical upward SV stress wave; the related fast Fourier transform (FFT) ensures negligible spectral amplitudes for frequencies higher than $10 \mathrm{~Hz}$. To avoid numerical errors during dynamic calculation, the function has a symmetrical shape and a null integral on the total time.

[79] Mechanical dissipation was computed using a Rayleigh Damping function; in the numerical model, the minimum circular frequency, $\omega_{\min }$, and the minimum damping, $\xi_{\min }$, were fixed to 1 and 0.01 , respectively, in order to obtain a damping coefficient lower than $5 \%$ in the frequency range $0-10 \mathrm{~Hz}$. The $80 \mathrm{~m}$ square grid ensures a frequency resolution up to about $4 \mathrm{~Hz}$. A seismic amplification function $(A(f))$ was obtained for the Mount Etna case by computing the acceleration spectral ratios between the receivers along the slope surface and the outcropping bedrock; nevertheless, according to this function, no significant amplification results, since $A(f)$ values up to 1.5 were computed within the whole range of frequency resolution.

[80] To analyze the numerical results, stress values were computed only along the SEC vertical scan line and were obtained by subtracting the stresses resulting from each scenario to the ones resulting under initial static conditions; the resulting differential stress values $(\Delta \sigma)$ correspond to relaxation in the case of tensile values and to contraction in the case of compressive ones. Strain effects were derived for all the considered scan lines (V1-V4) in terms of horizontal and vertical displacements ( $x$ disps and $y$ disps, respectively) induced by the internal and external forcing related to each simulated scenario. In the case of seismic scenarios, the resulting permanent displacements along the vertical scan lines were computed by subtracting from each resulting value the displacement due to the inertial movement of the whole model (i.e., measured at the bottom of the modeled area). The eruptive and inner pressure scenarios were simulated by applying static pressures within the model domain, reaching a new equilibrium and subtracting again the forcing pressure, in order to obtain the effective permanent stress-strain variation.

[81] The dynamic scenarios were modeled by applying a horizontally polarized SV wave seismic input which vertically propagated toward the surface from an elastic plane at quiet boundary conditions. The input was applied at the bottom of the model as a stress time history in the form:

$$
\sigma_{s}(t)=2 \rho C_{s} v_{s}(t)
$$

where $\sigma_{s}$ is the shear stress, $\rho$ is the density, $C_{s}$ is the $S$ wave velocity, and $v_{s}(t)$ is the velocity time history. The LEMA_DES-derived time histories of Figure 5 which were applied to the model correspond to multifrequential dynamic equivalent signals [Lenti and Martino, 2010] that enable control on the frequency, as well as on the energy content and on the peak ground acceleration (PGA) of the derived inputs, and guarantee a shorter time duration of the equivalent signal with respect to the reference one, thus enabling a proportionally long-duration dynamic simulations to ensure a complete damping effect in the postseismic phase. The displacements resulting from this dynamic modeling represent the permanent strain effect due to the seismic wave propagation through the volcanic edifice.

[82] More in particular, in the case of both $M=7$ far-field earthquake and local LP seismic events, the dynamic equivalent signals were derived by the LEMA_DES approach, by averaging the reference fast Fourier transform (FFT) of the two recorded accelerograms.

[83] For the seismic scenario a, according to the Italian attenuation law [Sabetta and Pugliese, 1987], attenuation effects were neglected along the here analyzed geological section, since its distance to the closest (i.e., the most dangerous) possible source is lower than $30 \mathrm{~km}$ (Figures 1a and 4). On the other hand, in the case of the seismic scenario b, the expected epicentral distances are so large (i.e., $>500 \mathrm{~km}$ ) to make it possible to neglect attenuation effects according to the Greece attenuation laws [Papazachos et al., 1993; Ambraseys et al., 1996]. Conversely, in the case of the nearfield LP earthquakes (scenario c), seismic attenuation could not be neglected and a local ground motion scaling, proposed for eastern Sicily by Scognamiglio et al. [2005], was taken into account in order to differentiate the seismic input along the lower boundary of the numerical model. This scaling law follows the approach described by Malagnini et al. [2000, 2002]. A random vibration theory (RVT) was applied in order to obtain a quantitative evaluation of the apparent geometrical spreading $g(r)$, of the crustal quality factor $Q(f)$, and of the attenuation parameter $j_{0}$, related to a reference rock site; the attenuation and source parameters estimated in this study are used through the RVT in order to predict the peak horizontal ground acceleration (PGA), and the 5\% damping pseudoacceleration spectra. According to the assumed attenuation law, the PGA is reduced up to 1 order of magnitude within a radius of about $50 \mathrm{~km}$ from the epicenter. More in particular, three different epicenter locations were modeled (at distances of 2800,7760 , and $11,760 \mathrm{~m}$ from the SEC, respectively), following the epicenter distribution of the LP events recorded during the 2002 seismic swarm [Milana et al., 2008].

[84] Acknowledgments. This research was carried out within: (1) the Italian national project "Gravitational instabilities of the eastern flank of the Etna volcano: Numerical modeling of the stress-strain effects induced by static inner pressures and dynamic actions" (responsible Francesca Bozzano), funded by Sapienza-Università di Roma (Year 2008 - prot. C26F08T34A); (2) the Italian national project "Landslide triggering in areas affected by intense morphodynamics due to volcanism, seismicity and erosional processes" (responsible Salvatore Martino), funded by Sapienza-Università di Roma (Year 2012 -prot. C26A12MT4F). We thank G. Groppelli and A. Gudmundsson for their helpful reviews.

\section{References}

Acocella, V. (2005), Modes of sector collapse of volcanic cones: Insights from analogue experiments, J. Geophys. Res., 110, B02205, doi:10.1029/ 2004JB003166.

Acocella, V., and M. Neri (2003), What makes flank eruptions? The 2001 Etna eruption and its possible triggering mechanisms, Bull. Volcanol., 65, $517-529$. 
Acocella, V., B. Behncke, M. Neri, and S. D’Amico (2003), Link between large-scale flank slip and 2002-2003 eruption at Mt. Etna (Italy), Geophys. Res. Lett., 30, 2286, doi:10.1029/2003GL018642.

Allard, P., M. Burton, and F. Murè (2005), Spectroscopic evidence for a lava fountain driven by previously accumulated magmatic gas, Nature, 433, 407-410.

Aloisi, M., O. Cocina, G. Neri, B. Orecchio, and E. Privitera (2002), Seismic tomography of the crust underneath the Etna volcano, Sicily, Phys. Earth Planet. Inter., 134, 139-155.

Ambraseys, N. N., K. A. Simpson, and J. J. Bommer (1996), Prediction of horizontal response spectra in Europe, Earthquake Eng. Struct. Dyn., 25, $371-400$.

Ambraseys, N., P. Smit, R. Berardi, D. Rinaldis, F. Cotton, and C. Berge-Thierry (2000), Dissemination of European strong-motion data, CD-ROM collection, European Council, Environment and Climate Research Programme.

Andrade, S. D., and B. Van Wyk de Vries (2010), Structural analysis of the early stages of catastrophic stratovolcano flank-collapse using analogue models, Bull. Volcanol., 72, 771-789.

Andronico, D., S. Scollo, S. Caruso, and A. Cristaldi (2008), The 2002-03 Etna explosive activity: Tephra dispersal and features of the deposits, J. Geophys. Res., 113, B04209, doi:10.1029/2007JB005126.

Apuani, T., M. Masetti, and M. Rossi (2007), Stress-strain-time numerical modelling of a deep-seated gravitational slope deformation: Preliminary results, Quat. Int., 171-172, 80-89.

Apuani, T., C. Corazzato, A. Merri, and A. Tibaldi (2013), Understanding Etna flank instability through numerical models, $J$. Volcanol. Geotherm. Res., 251, 112-126.

Azzaro, R., and M. S. Barbano (2000), Analysis of the seismicity of Southeastern Sicily: A proposed tectonic interpretation, Ann. Geophys. $43,171-188$

Azzaro, R., D. Bella, L. Ferreli, A. M. Michetti, F. Santagati, L. Serva, and E. Vittori (2000), First study of fault trench stratigraphy at Mt. Etna volcano, Southern Italy: Understanding Holocene surface faulting along the Moscarello fault, J. Geodyn., 29(3-5), 187-210.

Azzaro, R., S. Branca, K. Gwinner, and M. Coltelli (2012), The volcanotectonic map of Etna volcano, 1:100.000 scale: An integrated approach based on a morphotectonic analysis from high-resolution DEM constrained by geologic, active faulting and seismotectonic data, Ital. J. Geosci., 131(1), $153-170$

Barberi, G., O. Cocina, V. Maiolino, C. Musumeci, and E. Privitera (2004), Insight into Mt. Etna (Italy) kinematics during the 2002-2003 eruption as inferred from seismic stress and strain tensors, Geophys. Res. Lett., 31 , L21614, doi:10.1029/2004GL020918.

Barla, G., M. Borri Brunetto, and L. Vai (1990), Un esempio di modellazione matematica in rocce tenere la Rupe di Orvieto, in Proc. 3rd Conference on Rock Mechanics and Eng, vol. 14, pp. 1-12, Technical University, Torino.

Behncke, B., M. Neri, E. Pecora, and V. Zanon (2006), The exceptional activity and growth of the Southeast Crater, Mount Etna (Italy), between 1996 and 2001, Bull. Volcanol., 69, 149-173.

Bonaccorso, A. (1996), A Dynamic inversion for modelling volcanic sources through ground deformation data (Etna 1991-92), Geophys. Res. Lett., 23(5), 451-454

Bonaccorso, A. (2006), Explosive activity at Mt. Etna summit craters and source modelling by using high precision continuous tilt, J. Volcanol. Geotherm. Res., 158, 221-234.

Bonaccorso, A., R. Velardita, and L. Villari (1994), Ground deformation modelling of geodynamic activity associated with the 1991-1993 Etna eruption, Acta Vulcanol., 4, 87-96.

Bonaccorso, A., M. Aloisi, and M. Mattia (2002), Dike emplacement forerunning the Etna July 2001 eruption modeled through continuous tilt and GPS data, Geophys. Res. Lett., 29(13), 1624, doi:10.1029/2001GL014397.

Bonaccorso, A., G. Currenti, and C. Del Negro (2013), Interaction of volcano-tectonic fault with magma storage, intrusion and flank instability: A thirty years study at Mt. Etna volcano, J. Volcanol. Geotherm. Res., 251, 127-136.

Bonforte, A., F. Guglielmino, M. Palano, and G. Puglisi (2004), A syneruptive ground deformation episode measured by GPS, during the 201 eruption on the upper southern flank of Mt. Etna, Bull. Volcanol., 66, 336-341.

Borgia, A., L. Ferrari, and G. Pasquarè (1992), Importance of gravitational spreading in the tectonic and volcanic evolution of Mount Etna, Nature, 357, 231-235.

Borgia, A., R. Lanari, E. Sansosti, M. Tesauro, P. Berardino, G. Fornaro, M. Neri, and J. B. Murray (2000), Actively growing anticlines beneath Catania from the distal motion of Mount Etna's décollement measured by SAR interferometry and GPS, Geophys. Res. Lett., 27, 3409-3412.

Bozzano, F., S. Martino, and M. Priori (2006), Natural and man-induced stress evolution of slopes: The Monte Mario hill in Rome, Environ. Geol., 50, 505-524.
Bozzano, F., S. Martino, A. Montagna, and A. Prestininzi (2012), Back analysis of a rock landslide to infer rheological parameters, Eng. Geol., 131-132, 45-56.

Branca, S., and V. Ferrara (2013), The morphostructural setting of Mount Etna sedimentary basement (Italy): Implications for the geometry and volume of the volcano and its flank instability, Tectonophysics, 586, 46-64.

Branca, S., M. Coltelli, G. Groppelli, and G. Pasquarè (2009), Foglio 625-Acireale, Carta Geologica d'Italia 1:50.000, ISPRA, Servizio Geologico d'Italia.

Branca, S., M. Coltelli, and G. Groppelli (2011a), Geological evolution of a complex basaltic stratovolcano: Mount Etna, Italy, Ital. J. Geosci., 130(3), 306-317.

Branca, S., M. Coltelli, G. Groppelli, and F. Lentini (2011b), Geological map of Etna volcano, 1:50,000 scale, Ital. J. Geosci., 130(3), 265-291.

Brune, J. (1970), Tectonic stress and the spectra of seismic shear waves from earthquakes, J. Geophys. Res., 75, 4997-5009.

Calvari, S., M. Coltelli, M. Pompilio, and V. Scribano (1991), Analysis of three strong explosive episodes in recent activity at Mt. Etna volcano (Italy), Eos Trans. AGU, 72(44), Fall Meet. Suppl., 561.

Calvari, S., G. Groppelli, and G. Pasquarè (1994), Preliminary geological data on the south-western walls of Valle del Bove, Mt. Etna (Sicily), Acta Vulcanol., 5, 15-30.

Calvari, S., L. H. Tanner, and G. Groppelli (1998), Debris-avalanche deposits of the Milo Lahar sequence and the opening of the Valle del Bove on Etna volcano (Italy), J. Volcanol. Geotherm. Res., 87, 193-209.

Calvari, S., L. H. Tanner, G. Groppelli, and G. Norini (2004), A comprehensive model for the opening of the Valle del Bove depression and hazard evaluation for the eastern flank of Etna volcano, in Mt. Etna: Volcano Laboratory, Geophysical Monograph, vol. 143, edited by A. Bonaccorso et al., pp. 65-75, AGU, Washington, D. C.

Carbone, D., G. Budetta, and F. Greco (2003), Bulk processes prior to the 2001 Mount Etna eruption, highlighted through microgravity studies, J. Geophys. Res., 108(B12), 2556, doi:10.1029/2003JB002542.

Catalano, S., S. Torrisi, and C. Ferlito (2004), The relation between Late Quaternary deformation and volcanism of Mt. Etna (eastern Sicily) New evidence from the sedimentary substratum in the Catania region, J. Volcanol. Geotherm. Res., 132, 311-334.

CFTI04 Med (2004), Catalogue of strong earthquakes in Italy 461 B.C.1997 and Mediterranean area 760 B.C. -1500 , An advanced laboratory of historical seismology by Guidoboni E., Ferrari G., Mariotti D., Tarabusi G. and Valensise G.[Available at http://storing.ingv.it/cfti4med/.].

Cianetti, S., C. Giunchi, and E. Casarotti (2012), Volcanic deformation and flank instability due to magmatic sources and frictional rheology: The case of Mount Etna, Geophys. J. Int., 191, 939-953, doi:10.1111/j.1365246X.2012.05689.x.

Clague, D. A., and R. P. Denlinger (1994), The role of olivine cumulates in destabilising the flank of Hawaiian volcanoes, Bull. Volcanol., 56, 425-434.

Coltelli, M., V. H. Garduño, M. Neri, G. Pasquarè, and M. Pompilio (1994), Geology of northern wall of Valle del Bove, Etna (Sicily), Acta Vulcanol., $5,55-68$.

Coltelli, M., P. Del Carlo, and L. Vezzoli (1998), The discovery of a Plinian basaltic eruption of Roman age at Etna volcano, Italy, Geology, 26, 1095-1098.

Corsaro, R. A., and M. Pompilio (2004), Magma dynamics in the shallow plumbing system of Mt. Etna as recorded by compositional variations in volcanics of recent summit activity (1995-1999), J. Volcanol. Geotherm. Res., 137, 55-71.

Corsaro, R. A., R. Cristofolini, and L. Patanè (1996), The 1669 eruption at Mount Etna-Chronology, petrology and geochemistry, with inferences on the magma sources and ascent mechanisms, Bull. Volcanol., 58(5), 348-358

Corsaro, R. A., M. Neri, and M. Pompilio (2002), Paleo-environmental and volcanotectonic evolution of the south-eastern flank of Mt. Etna during the last $225 \mathrm{ka}$ inferred by the volcanic succession of the Timpe, Acireale, Sicily, J. Volcanol. Geotherm. Res., 113, 289-306.

CPTI04 (2004), The 2004 Version of the Parametric Catalogue of Italian Earthquakes, edited by P. Gasperini et al., INGV, Bologna. [Available at http://emidius.mi.ingv.it/CPTI04.]

CPTI11 (2011), The 2011 Version of the Parametric Catalogue of Italian Earthquakes, edited by A. Rovida et al., INGV, Bologna. [Available at http://emidius.mi.ingv.it/CPTI11.]

Crisci, G. M., S. Di Gregorio, R. Rongo, M. Scarpelli, W. Spataro, and S. Calvari (2003), Revisiting the 1669 Etnean eruptive crisis using a cellular automata model and implications for volcanic hazard in the Catania area, J. Volcanol. Geotherm. Res., 123, 211-230.

Cristofolini, R., and C. Ferlito (1991), Evidenze dei corpi subvulcanici poco profondi nella successione etnea lungo le pareti occidentali della Valle del Bove, Mem. Soc. Geol. Ital., 47, 485-493. 
Davidson, J. P., and S. L. De Silva (1999), Composite volcanoes, in Encyclopedia of Volcanoes, edited by H. Sigurdsson, pp. 663-681, Academic Press, San Diego.

Day, S. J., J. C. Carracedo, H. Guillou, and P. Gravestock (1999a), Recent structural evolution of the Cumbre Vieja volcano, La Palma, Canary Islands, J. Volcanol. Geotherm. Res., 94, 135-167.

Day, S. J., S. I. N. Heleno da Silva, and J. F. B. D. Fonseca (1999b), A past giant lateral collapse and present day flank instability of Fogo, Cape Verde Islands, J. Volcanol. Geotherm. Res., 94, 191-218.

DBMI11 (2011), Database Macrosismico Italiano, edited by M. Locati, R. Camassi, and M. Stucchi, [Available at http://emidius.mi.ingv.it/DBMI11/.] De Beni, E., S. Branca, M. Coltelli, G. Groppelli, and J. R. Wijbrans (2011), ${ }^{40} \mathrm{Ar} /{ }^{39} \mathrm{Ar}$ isotopic dating of Etna volcanic succession, Ital. J. Geosci., 130, 292-305.

de Rita, D., G. Frazzetta, and R. Romano (1991), The Biancavilla-Montalto ingnimbrite (Etna, Sicily), Bull. Volcanol., 53, 121-131.

De Silva, S. L., J. P. Davidson, I. W. Croudace, and A. Escobar (1993), Volcanological and petrological evolution of volcan Tata Sabaya, SW Bolivia, J. Volcanol. Geotherm. Res., 55, 305-335.

DISS03 (2003), Database of Individual Seismogenetic Sources, [Available at http://diss.rm.ingv.it/diss/.].

Dobran, F., and S. Coniglio (1996), Magma ascent simulations of Etna's eruptions aimed at internal system definition, J. Geophys. Res., 101, 713-731, doi:10.1029/95JB02248

Donnadieu, F., and O. Merle (1998), Experiments on the indentation process during cryptodome intrusions: New insights into Mount St. Helens deformation, Geology, 26(1), 79-82.

Duffield, W. A., R. L. Christiansen, R. Y. Koyanagi, and D. W. Peterson (1982), Storage, migration, and eruption of magma at Kilauea volcano, Hawaii, 1971-1972, J. Volcanol. Geotherm. Res., 13, 273-307.

Duncan, A. M. (1976), Pyroclastic flow deposits in the Adrano area of Mount Etna, Sicily, Geol. Mag., 113, 357-363.

Esposito, C., S. Martino, and G. Scarascia Mugnozza (2007), Mountain slope deformations along thrust fronts in jointed limestone: An equivalent continuum modelling approach, Geomorphology, 90(1-2), 55-72.

Ferrari, L., V. H. Garduño, and M. Neri (1991), I dicchi della Valle del Bove, Etna: un metodo per stimare le dilatazioni di un apparato vulcanico, Mem. Soc. Geol. Ital., 47, 495-508.

Froger, J. L., O. Merle, and P. Briole (2001), Active spreading and regional extension at Mount Etna imaged by SAR interferometry, Earth Planet. Sci. Lett., 187, 245-258.

Giachetti, T., R. Paris, K. Kelfoun, and F. J. Perez-Torrado (2011), Numerical modelling of the tsunami triggered by the Guımar debris avalanche, Tenerife (Canary Islands): Comparison with field based data, Mar. Geol., 284, 189-202.

Giordano, D., and D. B. Dingwell (2003), Non-Arrhenian multicomponent melt viscosity: A model, Earth Planet. Sci. Lett., 208, 337-349.

González, P. J., K. F. Tiampo, A. G. Camacho, and J. Fernández (2010), Shallow flank deformation at Cumbre Vieja volcano (Canary Islands): Implications on the stability of steep-sided volcano flanks at oceanic islands, Earth Planet. Sci. Lett., 297(3-4), 545-557.

Groppelli, G., and A. Tibaldi (1999), Control of rock rheology on deformation style and slip-rate along the active Pernicana fault, Mt. Etna, Italy, Tectonophysics, 305, 521-537.

Grunthal, G. (1998), European macroseismic scale 1998, Cah. Cent. Eur. Geodyn. Deism., 15, 1-99.

Gudmundsson, A. (1999), Injection and arrest of dykes: Implications for volcanic hazards, J. Volcanol. Geotherm. Res., 88, 1-13.

Guest, J. E., D. K. Chester, and A. M. Duncan (1984), The Valle del Bove: Its origin and relation to the stratigraphy and structure of the volcano, J. Volcanol. Geotherm. Res., 21, 1-23.

Holcomb, R. T., and R. C. Searle (1991), Catastrophic collapse of the volcanic island of Hierro $15 \mathrm{ka}$ ago and the history of landslides in the Canary Islands, Geology, 24, 231-234.

ITASCA (2011), FLAC 7.0: User manual. Licence number 213-039-012730821, University of Rome “Sapienza," Dipartimento di Scienze della Terra.

Jousset, P., and J. Douglas (2007), Long-period earthquake ground displacements recorded on Guadeloupe (French Antilles), Earthquake Eng. Struct. Dyn., 36, 949-963.

Kouskouna, V., and K. C. Makropoulos (2004), Historical earthquake investigations in Greece, Ann. Geophys., 47(2/3), 723-731

Lagmay, A. M. F., B. van Wyk de Vries, N. Kerle, and D. M. Pyle (2000), Volcano instability induced by strike-slip faulting, Bull. Volcanol., 62, 331-346.

Lenti, L., and S. Martino (2010), New procedure for deriving multifrequential dynamic equivalent signals (LEMA_DES): A test-study based on Italian accelerometric records, Bull. Earthquake Eng., 8, 813-846.

Lentini, F. (1982), The geology of the Mt. Etna basement, Mem. Soc. Geol. Ital., 23, 7-25.

Lipman, P. W., and D. R. Mullineaux (1981), Report: The 1980 eruptions of Mount St. Helens, Washington (U.S.), USGS Prof. Pap., 1250, 844 pp.
Lundgren, P., P. Berardino, M. Coltelli, G. Fornaro, R. Lanari, G. Puglisi, E. Sansosti, and M. Tesauro (2003), Coupled magma chamber inflation and sector collapse slip observed with synthetic aperture radar interferometry on Mt. Etna volcano, J. Geophys. Res., 108(B5), 2247, doi:10.1029/ 2001JB000657.

Maffei, A., S. Martino, and A. Prestininzi (2005), From the geological to the numerical model in the analsis of the gravity-induced slope deformations: An example from the Central Apennines (Italy), Eng. Geol., 78, 215-236.

Malagnini, L., R. B. Hermann, and K. Koch (2000), Regional ground motion scaling in central Europe, Bull. Seismol. Soc. Am., 90, 1052-1061.

Malagnini, L., A. Akinci, R. B. Hermann, N. A. Pino, and L. Scognamiglio (2002), Characteristics of the ground motion in northeastern Italy, Bull. Seismol. Soc. Am., 92, 2186-2204.

Masson, D. G. (1996), Catastrophic collapse of the flank of El Hierro about 15,000 years ago, and the history of large flank collapses in the Canary Islands, Geology, 24, 231-234.

Mastin, L. G., and M. S. Ghiorso (2000), A numerical program for steadystate flow of magma-gas mixtures through vertical eruptive conduits, U.S. Geological Survey Open-File Report, 00-209, pp. 1-59.

McGuire, W. J. (1982), Evolution of the Etna volcano: Information from the southern wall of the Valle del Bove caldera, J. Volcanol. Geotherm. Res. $13,241-271$

McGuire, W. J. (1996), Volcano instability: A review of contemporary theme, in Volcano Instability on the Earth and Other Planets, Geol. Soc. Lond. Spec. Publ., vol. 110, edited by W. J. McGuire, A. P. Jones, and J. Neuberg, pp. 1-23, London, U. K.

McGuire, W. J. (2006), Lateral collapse and tsunamigenic potential of marine volcanoes, Geol. Soc. Lond. Spec. Publ., 269, 121-140.

McGuire, W. J., A. D. Pullen, and S. J. Saunders (1990), Recent dyke induced large-scale block movement at Mount Etna and potential slope failure, Nature, 343, 357-359.

McGuire, W. J., A. P. Jones, and J. Neuberg (1996), Volcano Instability on the Earth and Other Planets, Geol. Soc. Lond. Spec. Publ., vol. 110, 389 pp., London, U. K.

Medley, E. (1999), Systematic characterization of melange bimrocks and other chaotic soil/rock mixtures, Felsbau, 17(3), 152-162.

Merle, O., and A. Borgia (1996), Scaled experiments of volcanic spreading, J. Geophys. Res., 101, 13,805-13,817.

Métrich, N., and M. J. Rutherford (1998), Low pressure crystallization paths for $\mathrm{H}_{2} \mathrm{O}$-saturated basaltic-hawaiitic melts from Mt Etna: Implications for open-system degassing of basaltic volcanoes, Geochim. Cosmochim. Acta, 62, 1195-1205.

Métrich, N., P. Allard, N. Spilliaert, D. Andronico, and M. Burton (2004), 2001 flank eruption of the alkali and volatile-rich primitive melt responsible for Mount Etna's evolution in the last three decades, Earth Planet. Sci. Lett. $228,1-17$.

Milana, G., A. Rovelli, A. De Sortis, G. Calderoni, G. Coco, M. Corrao, and P. Marsan (2008), The role of long-period ground motions on magnitude and damage of volcanic earthquakes on Mt. Etna, Italy, Bull. Seismol. Soc. Am., 98(6), 2724-2738.

Monaco, C., and L. Tortorici (2000), Active faulting in the Calabrian arc and eastern Sicily, J. Geodyn., 29, 407-424.

Moore, J. P., D. A. Clague, R. T. Holcomb, P. W. Lipman, W. R. Normark, and M. E. Torresan (1989), Prodigious submarine landslides in the Hawaiian Ridge, J. Geophys. Res., 94, 465-484.

Moore, J. G., W. R. Normark, and R. T. Holcomb (1994), Giant Hawaiian landslides, Annu. Rev. Earth Planet. Sci., 22, 119-144.

Murray, J. B. (1994), Elastic model of the actively intruded dyke feeding the 1991-1993 eruption of Mt Etna, derived from ground deformation measurements, Acta Vulcanol., 4, 97-99.

Neri, M., V. H. Garduño, G. Pasquarè, and R. Rasà (1991), Studio strutturale e modello cinematico della Valle del Bove e del settore nord-orientale etneo, Acta Vulcanol., 1, 17-24.

Neri, M., V. Acocella, and B. Behncke (2004), The role of the Pernicana Fault System in the spreading of Mt. Etna (Italy) during the 2002-2003 eruption, Bull. Volcanol., 66, 417-430.

Papazachos, B. C., C. A. Papaioannou, B. N. Margaris, and N. P. Theodulidis (1993), Regionalization of seismic hazard in Greece based on seismic sources, Nat. Hazards, 8, 1-18.

Patanè, G., A. Frasca, A. Agodi, and S. Imposa (1994), Earth tides and Etnean volcanic eruptions: An attempt of correlation of the two phenomena during the 1983, 1985 and 1986 eruptions, Phys. Earth Planet Inter., 87, 123-135

Patanè, D., P. De Gori, C. Chiarabba, and A. Bonaccorso (2003), Magma ascent and the pressurization of Mt. Etna's volcanic system, Science, 299, 2061-2063.

Patanè, D., G. Barberi, O. Cocina, P. De Gori, and C. Chiarabba (2006), Time resolved seismic tomography detects magma intrusions at Mt. Etna, Science, 313, 821-823.

Rasà, R., R. Azzaro, and O. Leonardi (1996), Aseismic creep on faults and flank instability at Mt. Etna volcano, Sicily, in Volcano Instability on the 


\section{BOZZANO ET AL.: MODELING FLANK INSTABILITY AT MOUNT ETNA}

Earth and Other Planets, Geol. Soc. Lond. Spec. Publ., vol. 110, edited by W. C. McGuire, A. P. Jones, and J. Neuberg, pp. 179-192, London, U. K.

Rollin, P. J., J. Cassidy, C. A. Locke, and H. Rymer (2000), Evolution of the magmatic plumbing system at Mt Etna: New evidence from gravity and magnetic data, Terra Nova, 12, 193-198.

Ruch, J., V. Acocella, F. Storti, M. Neri, S. Pepe, G. Solaro, and E. Sansosti (2010), Detachment depth of an unstable volcano revealed by rollover deformation: An integrated approach at Mount Etna, Geophys. Res. Lett., 37, L16304, doi:10.1029/2010GL044131.

Rust, D., and M. Neri (1996), The boundaries of large-scale collapse on the flanks of Mount Etna, Sicily, in Volcano instability on the Earth and Other Planets, Geol. Soc. Lond. Spec. Publ., vol. 110, edited by W. C. McGuire, A. P. Jones, and J. Neuberg, pp. 193-208, London, U. K.

Rust, D., B. Behncke, M. Neri, and A. Ciocanel (2005), Nested zones of instability in the Mount Etna volcanic edifice, Italy, J. Volcanol. Geotherm. Res., 144, 137-153.

Rymer, H., G. Brown, F. Ferrucci, and J. B. Murray (1994), Dyke intrusion mechanisms on Etna 1989-1993 and microgravity precursors to eruption, Acta Vulcanol., 4, 109-114.

Sabetta, F., and A. Pugliese (1987), Attenuation of the peak horizontal acceleration and velocity from Italian strong-motion records, Bull. Seismol. Soc. Am., 77, 1491-1511.

Scognamiglio, L., L. Malagnini, and A. Akinci (2005), Ground-motion scaling in eastern Sicily, Italy, Bull. Seismol. Soc. Am., 95(2), 568-578.

Scollo, S., M. Prestifilippo, G. Spata, M. D’Agostino, and M. Coltelli (2009), Monitoring and forecasting Etna volcanic plumes, Nat. Hazards Earth Syst. Sci., 9, 1573-1585.

Shaw, B., N. N. Ambraseys, P. C. England, M. A. Floyd, G. J. Gorman, T. F. G. Higham, J. A. Jackson, J. M. Nocquet, C. C. Pain, and M. D. Piggott (2008), Eastern Mediterranean tectonics and tsunami hazard inferred from the AD 365 earthquake, Nat. Geosci., 1, 268-276.
Siebert, L. (1984), Large volcanic debris avalanches: Characteristics of source areas, deposits, and associated eruptions, J. Volcanol. Geotherm. Res., 22, 163-197.

Siebert, L., H. Glicken, and T. Ui (1987), Volcanic hazards from Bezymianny- and Bandai-type eruptions, Bull. Volcanol., 49, 435-459.

Solaro, G., V. Acocella, S. Pepe, J. Ruch, M. Neri, and E. Sansosti (2010), Anatomy of an unstable volcano from InSAR: Multiple processes affecting flank instability at Mt. Etna, 1994-2008, J. Geophys. Res., 115, B10405, doi:10.1029/2009JB000820.

Sottili, G., and D. M. Palladino (2012), Tidal modulation of eruptive activity at open-vent volcanoes: Evidence from Stromboli, Italy, Terra Nova, 24(3), 233-237.

Sottili, G., S. Martino, D. M. Palladino, A. Paciello, and F. Bozzano (2007), Effects of tidal stresses on volcanic activity at Mount Etna, Italy, Geophys. Res. Lett., 34, L01311, doi:10.1029/2006GL028190.

Tibaldi, A., and G. Groppelli (2002), Volcano-tectonic activity along structures of the unstable NE flank of Mt. Etna 8Italy) and their possible origin, J. Volcanol. Geotherm. Res., 115, 277-302.

Vidal, N., and O. Merle (2000), Reactivation of basement faults beneath volcanoes: A new model of flank collapse, J. Volcanol. Geotherm. Res., 99, 9-26.

Voight, B., H. Glicken, R. J. Janda, and P. M. Douglass (1981), Catastrophic rockslide-avalanche on May 18, in The 1980 Eruption of Mount St. Helens, vol. 1250, edited by P. W. Lipman and D. R. Mullineaux, pp. 347-378, U.S. Geol. Surv. Prof. Pap., Washington, D. C.

Walter, T. R., R. Wang, V. Acocella, M. Neri, H. Grosser, and J. Zschau (2009), Simultaneous magma and gas eruptions at three volcanoes in southern Italy: An earthquake trigger?, Geology, 37, 251-254.

Waythomas, C. F. (2012), Landslides at stratovolcanoes initiated by volcanic unrest, in Landslides: Types, Mechanisms and Modeling, edited by J. J. Clague and D. Stead, pp. 37-49, Cambridge Univ. Press, Cambridge, U.K. 